\title{
Article
}

\section{Abrogating Stare Decisis by Statute: \\ May Congress Remove the Precedential \\ Effect of Roe and Casey?}

\author{
Michael Stokes Paulsen ${ }^{\dagger}$
}

\section{CONTENTS}

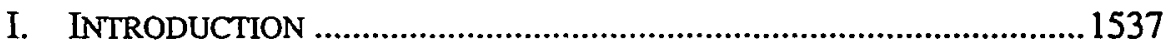

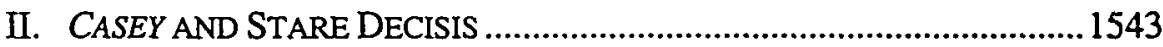

A. Stare Decisis as a Doctrine of Policy...........................................1543

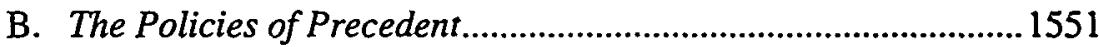

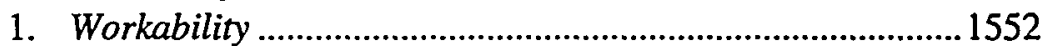

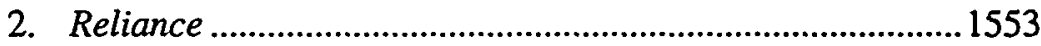

3. "Remnant of Abandoned Doctrine" ......................................1557

4. Changed Facts ....................................................................... 1562

5. Judicial Integrity ...............................................................1564

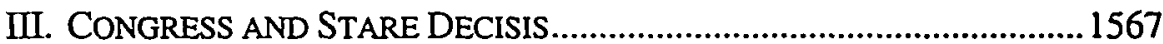

A. The Necessary and Proper Clause Power with Respect to the Judicial Process.

$\dagger$ Briggs \& Morgan Professor of Law, University of Minnesota Law School. My thanks to those who read and commented on earlier drafts, or with whom I discussed at length the ideas in this Article, none of whom should be blamed for the views expressed or the crrors that remain: Jim Chen, Brad Clark, Robert Delahunty, Dan Farber, Jill Fisch, David Fuller, Dan Gifford, Bill Kelley, Gary Lawson, Tom Lee, Chip Lupu, John Manning, Henry Monaghan, John Nagle, Saikrishna Prakash, and Suzanna Sherry. 
B. Does "[t]he Judicial Power" Entail an Autonomous

Constitutional Power of Courts To Prescribe a Doctrine

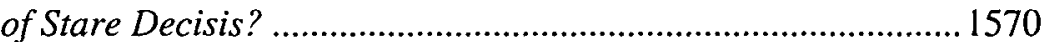

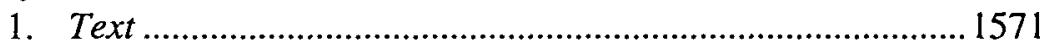

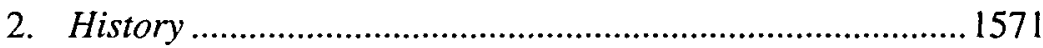

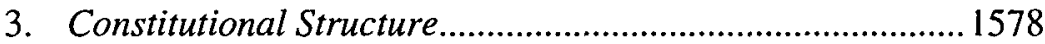

C. "Precedents" for Congressional Power in Matters of

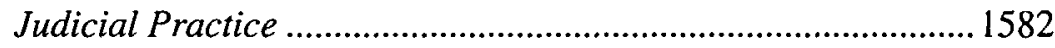

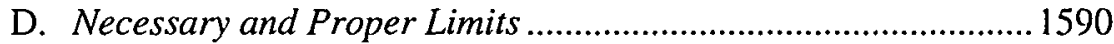

E. Other Possible Objections and Issues .......................................1594

IV. CoNCLUSION: BUT WILL IT FLY, WILBUR? ....................................1599 


\section{INTRODUCTION}

Stare decisis, the Supreme Court has often reminded us, is a rule of policy, not a rule of law. This is especially true in constitutional cases, the Court has said repeatedly, because of the difficulty of overtuming one of the Court's constitutional decisions by way of constitutional amendment.'

Nonetheless, the Court has occasionally relied on stare decisis as an apparently near-dispositive factor in deciding some extremely important constitutional cases, while at the same time continuing to express the view that stare decisis is not a doctrine of constitutional dimension. Most famously and recently, in Planned Parenthood v. Casey, ${ }^{2}$ the Court reaffirmed its controversial holding in Roe $v$. Wade ${ }^{3}$ recognizing a constitutional right to abortion, and did so largely on the basis of the policy of stare decisis. ${ }^{4}$ The Court was reluctant-especially so the three Justices authoring the "joint opinion" for the Court in the case (Justices O'Connor, Kennedy, and Souter)-to embrace as correct the substantive due process jurisprudence of Roe. The opinion expressed the apparent doubts of at least some of the Justices constituting the majority about the correctmess of Roe as an original matter and the morality of a constitutional right to abortion as a general proposition. Nonetheless, the policy of stare decisis persuaded a narrow majority (5-4) to reaffirm Roe, notwithstanding these reservations.

1. See, e.g., Agostini v. Felton, 521 U.S. 203. 235-36 (1997) (collecting cases and noting that stare decisis is "not an inexorable command" but "a policy judgment" that "is at its weakest when we interpret the Constitution because our interpretation can be altered only by constitutional amendment or by overnuling our prior decisions"); Seminole Tribe v. Florida, 517 U.S. 44, 63 (1996) ("[W]e always have treated stare decisis as a principlc of policy.... and not as an inexorable command.... When governing decisions are unworkable or are badly reasoned, this Court has never felt constrained to follow precedent. . . Our willingness to neconsider our carlier decisions has been particularly true in constitutional cases, because in such cases correction through legislative action is practically impossible." (internal quotation marks and citations omitted)); Payne v. Tennessee, 501 U.S. 808, 827-30 \& n.l (1991) (collecting cases); Patterson v. McLean Credit Union, 491 U.S. 164. 171-75 (1989); Glidden Co. v. Zdanok. 370 U.S. 530.543 (1962) (noting the Court's "considered practice not to apply stare decisis as rigidly in constitutional as in nonconstitutional cases"); Smith v. Allwright. 32I U.S. 649, 665 (1944) ("In constitutional questions ... this Court throughout its history has freely exereised its power to reexamine the basis of its constitutional decisions."); Helvering v. Hallock, 309 U.S. 106, 119 (1940) (noting that "stare decisis is a principle of policy and not a mathematical formula of adherence to the latest decision"); St. Joseph Stock Yards Co. v. United States, 298 U.S. 38, 94 (1936) (Stone \& Cardozo, JJ., concurring in the result) ("The doctrine of stare decisis ... has only a limited application in the field of constitutional law.").

2. 505 U.S. 833 (1992).

3. 410 U.S. 113 (1973).

4. See Casey, 505 U.S. at 854-69. Despite its exaltation of stare decisis, the Court in Casey partially overruled two other constitutional decisions conceming the scope of the judicially discovered right to abortion. See id. at 882 (overnuling in part Thomburgh v. American College of Obstetricians \& Gynecologists, 476 U.S. 747 (1986), and Ciny of Akron v. Akron Center for Reproductive Health, 462 U.S. 416 (1983)).

5. See id. at 861 ("Within the bounds of normal stare decisis analysis, then, and subject to the considerations on which it customarily turns, the stronger argument is for affirming Roe's central holding, with whatever degree of personal reluctance any of us may have, not for overnuling it."). 
I have criticized the Court's opinion in Casey in other writing, challenging its reliance on stare decisis and arguing that stare decisis is often merely a disingenuous "cover" for a decision made on other grounds. ${ }^{6}$ My goal here, however, is to take seriously the Court's stated reliance on stare decisis in Casey as a good-faith position sincerely adopted by the authors of the joint opinion. At the same time, I wish to take seriously the Court's position that stare decisis is neither a doctrine of constitutional dimension nor a strict rule of law, but rather is a subconstitutional doctrine of ostensibly wise judicial practice, procedure, and policy. Accepting both of these propositions, I wish to address whether Congress may abrogate stare decisis in a particular class of constitutional cases (or in federal question cases generally), and direct the federal courts to decide such cases ${ }^{7}$ in accordance with the courts' best present understanding of the meaning of the Constitution, without according prior judicial interpretations any decision-altering weight beyond the persuasiveness of their reasoning. The upshot of such a statute would be that courts would be obliged to overrule a prior interpretation of the Constitution if persuaded that the prior interpretation was incorrect on the merits. $^{8}$

6. See Michael Stokes Paulsen, Captain James T. Kirk and the Enterprise of Constitutional Interpretation: Some Modest Proposals from the Twenty-Third Century, 59 ALB. L. REv. 671, 679-81 (1995) [hereinafter Paulsen, Enterprise] (criticizing Casey and calling stare decisis "a hoax designed to provide cover for a particular outcome, not a genuine, principled ground of decision"); Michael Stokes Paulsen, Book Review, 10 CONST. COMMENTARY 221, 225-233 (1993) [hereinafter Paulsen, Book Review] (reviewing ROBERT A. BURT, THE CONSTITUTION IN CONFLICT (1992)); cf. Michael Stokes Paulsen \& Daniel N. Rosen, Brown, Casey-Style: The Shocking First Draft of the Segregation Opinion, 69 N.Y.U. L. REV. 1287 (1994).

7. There are special issues associated with selective statutory abrogation of stare decisis, which I discuss below. See infra text accompanying notes 167-171. I conclude that selective abrogation is constitutionally permissible, but across-the-board abrogation (at least for all constitutional cases) is preferable.

8. "Stare decisis" may be defined, crudely but not inaccurately, as the policy of adhering to precedent "whether or not mistaken." Casey, 505 U.S. at 857. The essence of the doctrine-the feature that gives the doctrine any genuine, independent weight in judicial decisionmaking (if it in fact does have such weight)-is adherence to earlier decisions, in subsequent cases, simply and purely because they were once decided a particular way, even though the court in the subsequent case otherwise would be prepared to say, based on other interpretive criteria, that the precedent decision's interpretation of law is wrong. One does not need a doctrine of stare decisis to explain a court's decision to adhere to a prior interpretation of law that it thinks is correct, on independent criteria. See Frederick Schauer, Precedent, 39 STAN. L. Rev. 571, 571 (1987) ("The bare skeleton of an appeal to precedent is easily stated: The previous treatment of occurrence $X$ in manner $Y$ constitutes, solely because of its historical pedigree, a reason for treating $X$ in manner $Y$ if and when $X$ again occurs."); id. at 575 ("[I]f we are truly arguing from precedent, then the fact that something was decided before gives it present value despite our current belief that the previous decision was erroneous."); cf. Henry P. Monaghan, Stare Decisis and Constitutional Adjudication, 88 COLUM. L. REV. 723, 755 (1988) (arguing that the essence of stare decisis is that "the second court must feel bound by the precedent").

I set to one side for purposes of this Article the interesting and important question of whether Congress may abrogate (or mandate) "vertical" stare decisis, in the sense of lower courts" generally accepted obligation to follow the decisions of the Supreme Court and other courts above them in the hierarchical chain of appeal. See infra note 169. In this Article. I focus on whether 
In treating this question, I will not indulge in the usual academic pretense (which is almost invariably a pretense) of dispassionate neutrality. I have written on the abortion issue before, and my view that Roe is fundamentally illegitimate (and immoral) is well-documented. ${ }^{9}$ Nor do I wish to hide my purpose here. My motivation for writing, revealed in the style of my presentation, is one that openly reflects a desire that Roe be overturned. ${ }^{10}$ My analysis, however (as distinguished from my motivation), is not, I hope, result-driven or result-bound. The skeptical reader may put that to the test: If sound, my thesis should be fully generalizable across the entire range of constitutional issues. If Congress may abrogate the stare decisis effect of Roe and Casey, in effect requiring the Court to reconsider the abortion issue on a clean slate, it may do the same for, say, Bowers $v$. Hardwick, ${ }^{11}$ a controversial constitutional holding that engenders equally strong views (reflecting, typically, different political alignments). ${ }^{12}$ The argument that I offer here is content-neutral. The merit of the argument does not depend on the issue for which it is advanced. Accordingly, I

Congress may relieve the Supreme Cour of the obligation to follow its prior cases interpreting some aspect of the Constitution, when the Supreme Court is convinced that the prior case is wrong and would not, but for the doctrine of stare decisis, follow or apply it.

9. See Michael Stokes Paulsen, Hell, Handbaskets, and Govemment Lawyers: The Dury of Loyalty and Its Limits, LAW \& CONTEMP. PROBS., Winter 1998, at 83 thereinafter Paulsen. Dury of Loyalty]; Michael Stokes Paulsen, Accusing Justice: Some Variations on the Themes of Robert M. Cover's Justice Accused, 7 J.L. \& RELIGION 33 (1989) [hereinafter Paulsen, Accusing Justice].

10. All good scholarship, I believe, entails some element of "advocacy." (And, conversely, all good advocacy entails some element of scholarship.) The veneer of neutrality, however, is often used by legal scholars to disguise an agenda. In my judgment, where such an agenda is covert, or where motivations are misrepresented, the veneer of academic objectivity becomes a species of borderline academic dishonesty. Far better, I think, to dispense with the veneer. Motivations should be disclosed honestly. In retum, honest arguments should be evaluated on their merits.

11. 478 U.S. 186 (1986) (finding that the Constitution does not protect homosexual conduct against state criminal prohibition).

12. Other prominent examples of currently controversial constitutional decisions that might be candidates for reconsideration if Congress were to abrogate stare decisis include Alden $v$. Maine, 119 S. C. 2240 (1999); Seminole Tribe v. Florida, 517 U.S. 44 (1996); and Buckley v. Valeo, 424 U.S. 1 (1976) (per curiam). Seminole Tribe and Alden were both decided on 5-4 voles and there is at least some reason to believe that Justice Scalia's votes for the controversial majority opinions rest in part on considerations of stare decisis. See Pennsylvania v. Union Gas Co., 491 U.S. 1, 34 (1989) (Scalia, J., concurring in part and dissenting in part) (arguing that because the case is "at least close... the mere venerability of an answer consistenuly adhered to for almost a century, and the difficulty of changing, or even clearly identifying, the intervening law that has been based on that answer, strongly argue against a change."). Scalia has sometimes decried the demise of stare decisis, see, e.g.. Harper v. Virginia Dep't of Taxation, 509 U.S. 86, $108-09$ (1993) (Scalia, J., concurring) (lamenting the era of the "prospectivity prineiple," because it "was marked by a newfound disregard for stare decisis"), and has sometimes criticized reliance on the doctrine, see, e.g., Casey, 505 U.S. at 993 (Scalia, J., concuring in par and dissenting in part) ("The Court's reliance upon stare decisis can best be described as contrived."): Payne v. Tennessee, 501 U.S. 808, 834-35 (1991) (Scalia, J., concurring) (observing that the doctrine of stare decisis, "to the extent it rests upon anything more than administrative convenience, is merely the application to judicial precedents of a more general principle that the settled practices and expectations of a democratic society should generally not be disturbed by the courts"). 
challenge the skeptical reader to substitute the issue of his or her choicewe all have our lists of most-despised precedents-as a way of testing the thesis. ${ }^{13}$

The issue that I have chosen is abortion, one of the most persistent, important, and divisive constitutional issues of our day, and one in which the doctrine of stare decisis recently has played a dramatic role. My proposition is simply this: If the position of the authors of the joint opinion in Casey was taken sincerely and in good faith, as part of an effort by selfconsciously moderate-conservative Justices like O'Connor and Kennedy to follow a policy of perceived "judicial restraint" (even though such a policy is not required as a matter of law and is not of constitutional dimension), Congress may by statute relieve the Court of the perceived necessity of following this policy by abrogating the policy of stare decisis. Congress may substitute its judgment about mere considerations of policy or prudence for the Court's, and may legitimately expect that the Court will abide by policy judgments made by Congress within the scope of its constitutional powers. What Congress may not do is substitute its judgment for that of the Court on the merits of a particular constitutional issue and direct the Court to abide by that judgment. The courts have the Article III power to decide constitutional cases on their merits. A statute abrogating stare decisis does not impair that power; it merely directs courts to carry out that constitutional power without regard to nonconstitutional policy or pragmatic considerations, where Congress has legislated a different policy with respect to such considerations.

It follows that Congress may, by prospective legislation-for abortion cases or any others-direct the Court to decide constitutional or statutory interpretation issues without regard to prior precedent (aside from the precedent's persuasive value to the Court on the merits). Mere nonconstitutional policy considerations supporting the judicial practice of stare decisis-reliance, predictability, stability, restraint, and the like-lie within the power of Congress to weigh and evaluate. The courts' practice in this regard is not an unalterable attribute of "[t]he judicial Power" vested by Article III. It is, rather, like other judge-made "prudential" limitations on the exercise of the judicial power, a form of "common law" followed by courts as a matter of judicial policy. Such common law may be displaced by an act of Congress. ${ }^{14}$ Thus, if Congress determines that the policy considerations typically thought to support a policy of stare decisis as the

13. I hope to treat the issues of the legitimacy and constitutional status of the doctrine of stare decisis more comprehensively, and in a non-subject-specific manner, in a future work, provisionally entitled The Pernicious Doctrine of Stare Decisis.

14. See generally Henry P. Monaghan, The Supreme Court 1974 Term-Foreword: Constitutional Common Law, 89 HARV. L. REV. 1 (1975) (arguing that numerous "constitutional" decisions of the Supreme Court should be understood as in reality a species of "constitutional common law" that Congress may displace by statute). 
judiciary's default rule should not, in a given class of cases, lead courts to decide such cases in ways contrary to what the courts otherwise would view as the correct interpretation of the Constitution, Congress may enact legislation so specifying. Indeed, the point should be almost obvious. The only question that should be at all troubling is why courts so often assume that they should follow precedent rather than the Constitution in cases where the two are believed or assumed to conflict..$^{15}$

By virtue of the Necessary and Proper Clause, Congress has enumerated legislative power to pass a statute abrogating stare decisis, as an enactment appropriate to the carrying into execution of the judicial power. The exercise of such legislative power would not intrude on any constitutional province of the judiciary; by the Supreme Court's own admission, stare decisis is merely a rule of policy. Nor would such a congressional enactment dictate how the courts are to decide any given case-how they are to come out on the merits on the abortion issue, for example, or on any other. Such a statute would merely direct courts to decide such cases in conformity with the Constitution and not to apply precedents to the contrary if they are persuaded that a precedent decision is not a sound interpretation of the Constitution. Finally (though this point is slightly more problematic), there is no persuasive reason why Congress could not limit such a bill, as a first step (or as the only step), to issues of substantive due process and abortion, or to any other specific subject matter. $^{16}$

In short, Congress may require the Supreme Cour to consider the question of whether the Constitution grants a right to abortion, the next time it arises, on a clean slate insofar as the precedential force of earlier abortion decisions is concerned. This could well lead to a result on the merits different from the one reached in Casey, even taking into account President Clinton's appointment of two Justices who likely suppor the result in Roe.

15. See infra note 38 (noting the arguments that have been advanced for the proposition that the doctrine of stare decisis is unconstitutional). One need not accept the bracing proposition that the practice of stare decisis is unconstitutional in order to accept the conclusion of this Article: that the policy of stare decisis is neither constitutionally required nor an inherent aspect of " [ $t$ ] judicial Power" of Article III, exempt from legislative alteration.

16. See infra text accompanying notes 167-171. The constitutionality of a statutory abrogation of stare decisis should not tum on the motives of Congress in enacting it, unless the motive itself is unconstitutional. A desire to see the Cour overtum Roe (or any other case) is not an illegitimate motive; it is improper only if the means employed by Congress to effectuate this motive are themselves unlawful - that is, if Congress attempts to dictate the way that the Coun decides the issue on the merits or to withdraw from judicial consideration factual or legal considerations that the Constitution requires federal courts to be free to consider. As I develop more fully below, the type of statute I advocate here would not dictate results, establish conclusive presumptions, or deny consideration of the merits of a constitutional issue in any respect. See infra text accompanying notes $155-160$. It simply would remove from consideration a set of policy factors that the Court itself has acknowledged, repeatedly and consistently. are not required by the Constitution and that consequently lie within the policy judgmant of Congress. See infra Section II.A. 
If at least two of the three Justices who authored the joint opinion in Casey (O'Connor, Kennedy, and Souter) were honest in the stated reasons for their votes, their reaffirmation of Roe rested almost entirely on the policy of adhering to precedent, "whether or not mistaken," 17 in order to spare the Court the damage to its prestige and to public perceptions of its legitimacy that the Justices feared might flow from refusing to adhere to its "watershed" precedents. ${ }^{18}$ If these Justices' votes in Washington $v$. Glucksberg ${ }^{19}$ are to be taken seriously, at least two of them have repudiated the notion that the doctrine of "substantive due process" provides a basis for the creation of new constitutional rights lacking a basis in either constitutional text or specific historical tradition. Judicial creation of new substantive due process rights, without such foundation, was exactly the methodology underlying Roe. To be sure, Glucksberg does not explicitly disapprove Roe or any other substantive due process decision that had gone before. But Glucksberg unquestionably undermines the doctrinal footing on which at least some of those decisions rest, a factor that undermines the justification for adhering to such decisions, even under the stare decisis analysis of Casey. ${ }^{20}$ After Glucksberg, the only thing that sustains Roe is the policy of stare decisis-and under Casey itself, that policy is at its weakest when subsequent decisions have impaired the rationale of the earlier precedent.

If it lies within the power of Congress to remove from the Court the perceived burden of being "tested by following" 21 -that is, of feeling compelled to adhere to decisions of the Court rendered years or decades ago, even if a majority of the Court today believes those decisions wrongand if the Court consequently can point to Congress as the body responsible for striking a different policy balance concerning considerations of reliance and stability (on which Casey rests so heavily), the result could well be different in the next abortion case. Put simply, if Roe no longer rests on anything other than stare decisis, and if Congress possesses the power to direct that stare decisis not be given decision-altering weight, Roe should fall, even under the reasoning of Casey. All Congress needs to do is pass a statute abrogating the pure stare decisis effect of Roe.

This result may well seem counterintuitive at first blush, primarily because of its unfamiliarity to lawyers, judges, and scholars accustomed to the common-law tradition and trained in its method. But unfamiliarity does not equal unconstitutionality, and the legal community has had such reactions before to ideas that seemed novel or radical departures from

17. Casey, 505 U.S. at 857.

18. Id. at 864-69; see also Paulsen, Book Review, supra note 6, at 225-33; infra Section II.B.

19. 521 U.S. 702 (1997).

20. See infra Subsection II.B.3.

21. Casey, 505 U.S. at 868 . 
accepted convention at the time, but that are now familiar and uncontroversial. ${ }^{22}$ The idea that Congress may abrogate stare decisis by statute may strike some as startling, but the test of its correctness should be the soundness of the reasoning supporting it, not its conformity with present convention.

In what follows, I fill in the details of the above thesis. Part Il focuses on the Supreme Court's articulation of the doctrine of stare decisis in Casey and other cases, and on its reliance on that doctrine in Casey. Part III discusses the constitutional power of Congress under the Necessary and Proper Clause to abrogate the default rule of stare decisis as a policy applied by federal courts in constitutional cases, addresses why Congress lacks a converse power to mandate stare decisis, and anticipates and responds to other potential constitutional objections. Part IV concludes with a consideration of such a statute's practical prospects in the Supreme Court.

\section{CASEY AND STARE DECISIS}

\section{A. Stare Decisis as a Doctrine of Policy}

Central to the opinion and decision in Casey is its discussion of stare decisis, set forth in Part III of the Court's opinion. The discussion begins this way:

The obligation to follow precedent begins with necessity, and a contrary necessity marks its outer limit. With Cardozo, we recognize that no judicial system could do society's work if it eyed each issue afresh in every case that raised it.... Indeed, the very concept of the rule of law underlying our own Constitution requires such continuity over time that a respect for precedent is, by definition, indispensable.... At the other extreme, a different necessity would make itself felt if a prior judicial ruling should come to be seen so clearly as error that its enforcement was for that very reason doomed. ${ }^{23}$

This is the closest the Court in Casey comes to suggesting that stare decisis is a doctrine of constitutional dimension, and it is not all that close. Stare decisis is conceded to be a matter of policy-a judicial practice rooted in pragmatic concerns. The judicial policy of stare decisis is described as a

22. It is interesting to compare the initial judicial and academic reaction. early in the twentieth century, to "severability" instructions from legislatures concerning what courts should do if a portion of a legislative enactment were found unconstitutional. As Professor Nagle notes, "State courts and commentators refused to accept the proposition that legislatures had authority to dictate to the courts the appropriate decision regarding severability." John Copeland Nagle. Severability, 72 N.C. L. REV. 203, 222 (1993) (collecting cases and commentaries).

23. Casey, 505 U.S. at 854 (citations omitted). 
function, first, of the perceived inability of the judicial system to operate if it had to "eye[ ] each issue afresh in every case." ${ }^{24}$ This is the sense in which the idea of precedent "begins with necessity."

A statute abrogating stare decisis in substantive due process abortion cases (or in some other limited category or categories) would not change that policy judgment, for the simple reason that it would not force reexamination of precedent "in every case." Indeed, it would not force reexamination in very many cases. ${ }^{25}$ Even working within Casey's terms, then, congressional abrogation of stare decisis, at least for a limited class of cases, should pose no serious difficulty in terms of the efficient operation of the judiciary.

The Court in Casey drew a connection between " $t$ ] he obligation to follow precedent" and the perceived burden on the judiciary of having to view each issue "afresh in every case that raised it." ${ }^{26}$ It is unclear how these two ideas are related, however. Precedent can be seen as potentially performing two quite different functions-an "information" function (providing prior and potentially persuasive thinking to a present interpreter) and a "disposition" function (dictating, to some degree, a present interpreter's action). Both functions potentially create efficiency gains in the judicial decision process, but they are gains of two different types that have little to do with each other. Consider first the information function of precedent. To the extent that the existence of precedents relieves courts of the need to reinvent the interpretive wheel (since some thinking on the issuc has occurred before), the efficiency gain from not having to "eye[ I each issue afresh in every case that raise[s] it" ${ }^{27}$ is achieved by a regular practice of consulting and carefully considering past decisions. But that function of precedent does not imply an obligation to follow case law. Indeed, the Court in Casey (and in numerous other decisions) has acknowledged that sometimes the Court should-even must-overrule a prior case. An obligation "to follow precedent" comes purely from the "disposition" function of precedent (in strong or weak form) ${ }^{28}$ This creates efficiency gains of a different sort, resulting not from having the benefit of prior thinking, but from not having to think very much at all past a certain point: A judge need only ascertain the content of the prior decision and determine whether that content applies to a subsequent case.

24. Id.

25. For discussion of whether selective abrogation of stare decisis might pose other constitutional problems, see infra text accompanying notes 167-171.

26. Casey, 505 U.S. at 854.

27. Id.

28. A "strong" rule of stare decisis would give dispositive effect to precedent. A "weak" version of such a rule would still give precedent decision-altering weight, independent of its persuasive value. Such weight would not be fully dispositive, however, but would be considered along with other factors. 
Unless stare decisis is an absolute rule-relieving courts even of the obligation of thinking about the prior thinking - the disposition function of precedent ("the obligation to follow precedent") does not relieve the judiciary of the need to "eye[ ] each issue afresh in every case" in which it arises. This may in fact end up impairing the efficient performance of the judiciary's functions: The judges and Justices must both determine the applicability and evaluate the merit of the prior case, not just read it to gain the benefit of that case's thinking about the issue. As precedents multiply, the judges must evaluate the applicability and merits of more and more cases, and their relationship to each other. On top of that, the judges must apply the Court's (shifting, selective, inconsistent, non-per-se) stare decisis analysis, to determine when a decision or decisions can and should be overruled, in whole or in part, and what constitutes the "essential holding" 29 of a precedent. This can involve a lot of additional work. Casey itself consumes fifteen pages of the U.S. Reports discussing stare decisis and ends up overruling in part two earlier abortion decisions. It is not at all clear that "the obligation to follow precedent," as articulated by the Court in Casey, creates any true judicial efficiency gains at all. Thus, even a statute abrogating stare decisis in all federal-question cases might not undermine the "efficiency" policy justification for the doctrine advanced by the Court in Casey.

The Court's analysis in Casey goes on to suggest that "the very concept of the rule of law" requires "continuity," concluding that a "respect" for precedent is, therefore, "indispensable." ${ }^{30}$ A statute abrogating stare decisis in a given class of cases does not challenge this policy assessment either, at least not as stated by the Court. Abrogating stare decisis-forbidding the practice of according dispositive or decision-altering weight to a prior precedent "whether or not mistaken" ${ }^{31}$ - is not inconsistent with according appropriate respect to precedent. "Respect" implies an obligation of due consideration, careful reflection, and deference to the fact that other intelligent and reflective judges have thought about an issue before and taken care to express their reasoning in writing. In short, "respect" for precedent means giving due regard to the full value of the "information function" served by a body of case law. But respect for precedent does not entail an obligation to follow it in all circumstances-the "disposition function." The Court itself does not treat stare decisis as a strict rule or assert that overruling precedent is inconsistent with the rule of law. ${ }^{32}$

29. Casey, 505 U.S. at 846 .

30. Id. at 854 .

31. Id. at 857 .

32. See Payne v. Tennessee, 501 U.S. 808.827 (1991) ("“[T]his Coun has never felt constrained to follow precedent." (quoting Smith v. Allwright, 321 U.S. 049.665 (1944))). Casey contains about as strong an argument as the Cour has ever made for stare decisis, and it still stops well short of saying the doctrine is of constitutional stature. The closest the Court in Casey comes 
According precedent proper respect could entail simply giving the decisions of prior courts respectful consideration and deference-perhaps even the benefit of the doubt in cases of uncertainty. A statute stating that prior decisions are not to be treated as binding on subsequent courts-which is what the Court itself has always said-and therefore should not be treated as controlling a decision in a subsequent case if the Justices are otherwise persuaded that the precedent decision was erroneous, does not contradict the proposition that according "respect" to precedent is an ingredient in the idea of the rule of law. (If it did, the Court's own willingness to overrule prior decisions would itself violate this principle, as would its actual decision in Casey, which overruled in material part two other constitutional decisions of the Court. $)^{33}$

The next paragraph of the Casey opinion confirms the view that respect for precedent does not imply an obligation to follow precedent:

to such a claim are its assertions later in the joint opinion that overly frequent overnuling "would overtax the country's belief in the Court's good faith," and that overruling "watershed" decisions (meaning especially controversial or divisive decisions that the Court nonetheless believes "call[ ] the contending sides of a national controversy to end their national division by accepting a common mandate" in the form of the Court's resolution, Casey, 505 U.S. at 867), in perceived response to public or political pressure, or as a consequence of changes in the Court's composition, "would subvert the Court's legitimacy." Id. at 866-67. The Court in Casey believed that public perceptions of the Court's legitimacy are linked with the nation's "very ability to sce itself through its constitutional ideals," and thus to "the rule of law." See id. at 868-69. When all is said and done, however, nothing in even the rhetoric of Casey is equivalent to an asscrtion that overruling of precedent is inconsistent with the rule of law. The most the Court was willing to say was that adhering to precedent furthers certain important rule-of-law values.

The only other times that the Court has made similarly strong statcments, it has still stopped well short of a claim that stare decisis is of constitutional status. See Hilton v. South Carolina Pub. Rys. Comm'n, 502 U.S. 197, 202, 203 (1991) (stating that "[t]ime and time again, this Court has recognized that 'the doctrine of stare decisis is of fundamental importance to the rule of law," but recognizing that "countervailing justifications for departing from our precedents" exist (quoting Welch v. Texas Dep't of Highways \& Pub. Transp., 483 U.S. 468, 494 (1987))); Patterson v. McLean Credit Union, 491 U.S. 164, 172 (1989) (calling stare decisis "a basic sclfgoverning principle within the Judicial Branch" but noting that it is a principle of policy only); $c f$. Plaut v. Spendthrift Farm, 514 U.S. 211, 225 (1995) (quoting Thomas Cooley's 1868 argument that the legislature may not "direct[ ] what particular steps shall be taken in the progress of a judicial inquiry"). Both Patterson and Hilton involved issues of statutory interpretation, where the Court has found considerations of stare decisis to have "special force." Hilton, 502 U.S. at 202. These cases, and others employing similar language, might be taken to suggest-but fall well short of themselves claiming-that the policy of stare decisis, in some form, is constitutionally required as part of "[t]he judicial Power" of Article III. As argued at length below, a direct assertion that stare decisis is of constitutional dimension would be inconsistent with a wealth of current and historical practice. See infra Section III.C. (That in itself is not dispositive, of course. Just as the policy of stare decisis should not control constitutional interpretation where a prior judicial understanding is found unpersuasive, so too current or historical practice cannot definitively establish that such a practice is consistent with the best reading of the Constitution. But it surely can be persuasive, as I argue below.)

33. See Casey, 505 U.S. at 882 (overnuling in part Thornburgh v. American College of Obstetricians \& Gynecologists, 476 U.S. 747 (1986), and City of Akron v. Akron Center for Reproductive Health, 462 U.S. 416 (1983)). 


\begin{abstract}
Even when the decision to overrule a prior case is not, as in the rare, latter instance, virtually foreordained, it is common wisdom that the rule of stare decisis is not an "inexorable command," and certainly it is not such in every constitutional case, see Burnet v. Coronado Oil \& Gas Co., 285 U.S. 393, 405-411 (1932) (Brandeis, J., dissenting). See also Payne v. Tennessee, 501 U.S. 808, 842 (1991) (Souter, J., joined by Kennedy, J., concurring); Arizona v. Rumsey, 467 U.S. 203, 212 (1984). Rather, when this Court reexamines a prior holding, its judgment is customarily informed by a series of prudential and pragmatic considerations designed to test the consistency of overruling a prior decision with the ideal of the rule of law, and to gauge the respective costs of reaffirming and overruling a prior case..$^{34}$
\end{abstract}

The "not an "inexorable command" language and the citation to the Brandeis dissent in Coronado Oil have become standard fare in the Court's cases discussing stare decisis, routinely used to illustrate the subconstitutional, policy-based nature of the doctrine. Several prominent examples exist in opinions by (or joined by) Justice O'Connor, Justice Kennedy, and Justice Souter, the coauthors of the joint opinion for the Court in Casey. Indeed, several examples post-date Casey. Most recently, in Agostini v. Felton, ${ }^{35}$ Justice O'Connor wrote the following for the Court (in an opinion joined by Justice Kennedy as part of the majority):

As we have often noted, "[s]tare decisis is not an inexorable command," Payne v. Tennessee, 501 U.S. 808, 828 (1991), but instead reflects a policy judgment that "in most matters it is more important that the applicable rule of law be settled than that it be settled right," Burnet v. Coronado Oil \& Gas Go., 285 U.S. 393, 406 (1932) (Brandeis, J., dissenting). That policy is at its weakest when we interpret the Constitution because our interpretation can be altered only by constitutional amendment or by overruling our prior decisions. ${ }^{36}$

34. Id. at 854

35. 521 U.S. 203 (1997).

36. Id. at 235; see also Seminole Tribe v. Florida. 517 U.S. 44. 63 (1996) (majority opinion of Rehnquist, C.J., joined by O'Connor, Scalia, Kennedy. \& Thomas, JJ.) (noting that the Coun has "always...treated stare decisis as a principle of policy... and not as an inexorable command," and that "[o]ur willingness to reconsider our earlier docisions has been particularly true in constitutional cases, because in such cases correction through legislative action is practically impossible" (emphasis added) (internal quotation marks omitted)); Adarand Constructors v. Peña, 515 U.S. 200, 231-35 (1995) (pan III-C of the opinion, by O'Connor. J., joined by Kennedy, J.) (embracing the view that " stare decisis is a principle of policy and not a mechanical formula of adherence to the latest decision, however recent and questionable" and finding "special justification" for overuling a precedent where the precedent is (1) "inconsistent with the decisions that came before it," (2) "lack[s] constitutional roots," or (3) "was an abrupt and largely unexplained departure from precedent, and of which [t]he great weight of scholarly 
Plainly, then, stare decisis, even under the regime of Casey and subsequent cases, is a matter of judicial policy. It is a judgment, not grounded in the Constitution, that "in most matters" it is more important that a legal issue be settled than that it be "settled right." 37

What if Congress's judgment differs? What if Congress thinks, either in general or in a specific category of cases, that it is more important that an issue be "settled right" than that it remain settled the way the Court resolved it at an earlier time, especially if a majority of the Court now believes that the earlier decision is wrong? What if Congress thinks that, for an issue as important as abortion (and a decision as controversial and divisive as $R o e$ ), it is more important that the constitutional issue be settled correctly? There is nothing in the Constitution-and nothing even in Casey - that says that the doctrine of stare decisis, in a strong or weak, rigid or selective form, is constitutionally required. It is, rather, pure judicial policy. Whether it is good or bad policy is not the point. The point is that stare decisis is a policy judgment, not a rule of law specified in the Constitution or clearly implicit in its provisions or overall structure. ${ }^{38}$

opinion ha[d] been critical" (internal quotation marks omitted) (last two alterations in original)); cf. City of Boeme v. Flores, 521 U.S. 507, 548 (1997) (O'Connor, J., dissenting) (making a similar argument that stare decisis does not require adherence to a "demonstrably wrong" and "recent" decision); id. at 565 (Souter, J., dissenting) ("I have serious doubts about the precedential value of the [Employment Division v. Smith, 494 U.S. 872 (1990),] rule and its entitlement to adherence."); Church of the Lukumi Babalu Ayc v. City of Hialeah, 508 U.S. 520, 571-76 (1993) (Souter, J., concurring in part and concurring in the judgment) (noting the factors supporting reconsideration of a constitutional ruling).

Significantly, Justice Souter's dissent in Boerne makes clear his view that Congress cun legitimately and constitutionally enact legislation that has the effect of requiring the Supreme Court to reconsider one of its earlier constitutional decisions. Indeed, such a vicw governed his vote in that case, as he concluded that the question of the constitutionality of the Religious Freedom Restoration Act depended on whether or not Smith was correctly decided and that full consideration of that issue was required in order to decide the case:

[T] his case should be set down for reargument permitting plenary reexamination of the issue. Since the Court declines to follow that course ... the constitutionality of the Act of Congress to enforce the free-exercise right cannot now be soundly decided. I would therefore dismiss the writ of certiorari as improvidently granted, and I accordingly dissent from the Court's disposition of this case.

Boerne, 521 U.S. at 565-66 (Souter, J., dissenting). Justice Breyer expressed a very similar view and joined the pertinent portions of Justice O'Connor's dissent addressing the relevance of stare decisis. See id. at 566 (Breyer, J., dissenting).

37. Agostini, 521 U.S. at 235 (quoting Bumet v. Coronado Oil \& Gas Co., 285 U.S. 393, 406 (1932) (Brandeis, J., dissenting)).

38. Indeed, it has been suggested that to the extent judges rely on the doctrine to follow precedents rather than (and contrary to) the Constitution, the doctrine of stare decisis is unconstitutional: The Constitution is paramount law, and must take precedence (no pun intended) over precedents that depart from it, under the reasoning of Marbury v. Madison, 5 U.S. (1 Cranch) 137 (1803). which declared that courts must prefer the Constitution to the act of a subordinate agency under the Constitution, when the two conflict. See Gary Lawson, The Constitutional Case' Against Precedent, 17 Harv. J.L. \& PUB. POL'Y 23. $27-28$ (1994) ("If the Constitution says $X$ and a prior judicial decision says $Y$, a court has not merely the power, but the obligation, to prefer the Constitution."); see also Charles J. Cooper, Stare Decisis: Precedent and Principle in Constitutional Adjudication, 73 CORNELL L. REv. 401, 408 (1988) (arguing that "judges are outh- 
Might it be argued that stare decisis is a doctrine of judicial policy but nonetheless a policy of quasi-constitutional status-a matter of "constitutional policy," as it were-and that the judiciary's development of the doctrine should be immune from alteration by the legislature? Although the Supreme Court has consistently emphasized that the doctrine is one of policy, it has not quite said that the doctrine is not of constitutional status; moreover, a statement that the policy of stare decisis is "of tundamental importance to the rule of law" ${ }^{39}$ arguably creates some sort of heightened status. Might the Court plausibly conclude that the doctrine of stare decisis is of constitutional status after all, with the exact scope and contours of the doctrine committed to the (exclusive and unreviewable) "constitutional policy" judgment of the judiciary?

Putting to one side the fact that such a view would be, well, unprecedented-departing significantly from everything that the Court has ever said about the status of the doctrine of stare decisis-and the somewhat greater embarrassment that the adoption of such a position would seem to depart from the very doctrine being embraced, ${ }^{\text {to }}$ the principal merit, and principal drawback, of the "constitutional policy" argument is its elusiveness (or, put less charitably, its slipperiness). A "constitutional policy" formulation might mean any of several things. First, it might mean that the Constitution itself prescribes some rule of stare decisis of determinate content (be it absolute, very strong, or relatively weak). Such a view would be difficult to take seriously. There is no textual support for such a rule; there is no "stare decisis clause" in the Constitution or anything that can fairly be read as creating one. Moreover, such a view seems to be exactly what the Supreme Court has consistently and repeatedly rejected, and the approach least consistent with the Court's actual practice.

bound to rule in accordance with the Constitution. not with prior opinions interpreting the Constitution"); Paulsen, Enterprise, supra note 6. at 680-81 (arguing that under the reasoning of Marbury and The Federalist No. 78, " the Constitution must always be given preference over the faithless acts of mere govemment agents contrary to the Constitution. If this proposition is tnue, it follows that no court should ever deliberately adhere to what it is fully persuaded are the erroneous constitutional decisions of the past. To do so is to act in deliberate violation of the Constitution."); $c f$. Paulsen, Accusing Justice, supra note 9, at 77-88 (arguing that lower-coun judges are not bound to adhere to higher-cour precedent that is unfuithful to the Constitution). One need not go this far in order to accept the milder proposition of this Article: that stare decisis, even if assumed to be a legitimate judicial policy, is not a policy of constitutional status, and thus. like other sub-constitutional judicial policies or practices, may be abrogated or modified by an act of Congress.

39. Hilton v. South Carolina Pub. Rys. Comm'n. 502 U.S. 197. 202 (1991) (citations omitted).

40. The doctrine of stare decisis. as employed and articulated by the Coun. is certainly elastic enough to permit a change in the stated basis for the doctrine: One of the notable tronies of the present doctrine of stare decisis is that it appears not to require adherence to the present doctrine of stare decisis. At the same time, however, a departure from existing stare decisis doctrine, in the name of creating a stronger doctrine of stare decisis (or asserting a constitutional basis for the doctrine), does seem to border on self-contradiction and indirectly supports the argument of this Article that the doctrine is one of alterable judicial policy. 
Nothing in the text, history or structure of the Constitution, in judicial precedent interpreting it, or in customary practice supports the conclusion that the Constitution itself prescribes a judicial policy of stare decisis having any determinate or readily identifiable content.

Alternatively, if by "constitutional policy" it is meant not that the Constitution itself prescribes a rule of stare decisis, but that it delegates to the judiciary discretionary power to make such rules, then the claim is no more tenable. There is no more textual basis for such a claim than there is for the claim that the Constitution itself prescribes a rule of stare decisis. There is no "stare decisis power" committed to the judiciary in these terms; and, as discussed more fully below, ${ }^{41}$ the case-deciding power is not readily transmogrified into a constitutional empowerment of judges at time $T$, to bind judges at time $T_{2}$ to constitutional interpretations that the later judges are fully persuaded are erroneous.

Finally, if "constitutional policy" is thought to mean that the Constitution prescribes a doctrine of stare decisis, but with indeterminate content, and that the judiciary is empowered to fill in the details, the suggestion is no less vulnerable to all of the above objections. At bottom, the doctrine of stare decisis is either of constitutional dimension or it is not. If it is of constitutional dimension and has content, Congress may not alter it. If it is of constitutional dimension but nonspecific content and the Constitution specifies the agency or department that supplies the content, Congress may not interfere with the judgment of that agency or department. But if the Constitution neither specifies the content of the doctrine of stare decisis, nor specifies that such content lies within the exclusive constitutional power of the judiciary to create and alter at will, then the policy of stare decisis simply cannot be said to be one of constitutional stature and must lie within the power of Congress to abrogate or modify, pursuant to the Necessary and Proper Clause.

It follows that the policy of stare decisis may be displaced by Congress. Were the Court to assert otherwise (in apparent contradiction of its own repeated statements, in Casey and elsewhere), it would be placing its own policy judgment, without constitutional basis, above the policy judgment of Congress. The Court has been accused of such usurpations before, of course. The question in this context, however, is whether the Justices who relied on stare decisis in Casey-Justices who sought to eschew judicial activism, who could not bring themselves to embrace Roe as correct, and who (assuming their good faith) resorted to stare decisis as a doctrine of supposed judicial restraint-would strike down an act of Congress that did nothing more than provide that the Court was to decide an important constitutional issue on the merits, using its own best constitutional

41. See infra Section III.B. 
judgment, without the additional burden imposed by the prudential rule of stare decisis. Were the Justices joining the joint opinion in Casey to strike down such an act, it would reveal stare decisis as a mask-a doctrine designed to provide cover for an unpopular or uncomfortable decision on the merits-and reveal at least Justice O'Connor's and Justice Kennedy's explanations for their votes in Casey to have been dishonest. ${ }^{42}$

One hopes that this is not the case. There is much in Casey that seems to suggest that the Justices authoring the joint opinion were concerned, perhaps above all else, with public perceptions of their personal integrity: They wanted to make it clear that their votes were never precommitted to overruling $R o e .{ }^{43}$ Taking the Justices at their word, and assuming their stated reliance on the nonconstitutional policy of stare decisis was honestly felt, the Justices who voted to reaffirm Roe on stare decisis grounds, despite reservations about its correctness, should defer to Congress's judgment balancing those policy considerations differently (unless Congress lacks constitutional power to legislate concerning matters of judicial policy at all, a point I take up below). ${ }^{4}$

\section{B. The Policies of Precedent}

An examination of the specific policy factors making up the doctrine of stare decisis, as set forth in Casey, tends to reinforce this conclusion, by illustrating the type of policy balancing in which the Court engages to determine whether and when to overrule prior constitutional decisions. Of the five factors identified in Casey as relevant to the policy balancequestions of (1) the "workability" of a prior case or line of cases; (2) the protection of reasonable reliance interests; (3) the erosion of a decision's doctrinal foundations by subsequent decisions; (4) changed factual circumstances; and (5) the need to preserve public impressions of judicial integrity-at least two of these (reliance and factual circumstances) involve precisely the type of social-policy determinations or legislative fact-finding that are quintessentially within the province of Congress. A strong case can be made that two of the other three involve pure policy matters as well. I will take up each of Casey's five factors in turn.

42. See Paulsen, Enterprise, supra note 6, at 681 (speculating that the Court's selective stated reliance on stare decisis may be a "Grand Hoax").

43. I have speculated elsewhere:

In an atmosphere poisoned by bitter confirmation disputes centering on the issue of abortion, by protestors on both sides besieging the Cour's grounds and by hysterical media attention, O'Connor, Kennedy, and Souter were concerned that no one have the impression that they had been "bought"-that they had given secret commitments on abortion as the price for a seat on the Supreme Cour.

Paulsen, Book Review, supra note 6, at 232-33.

44. See infra Part III. 


\section{Workability}

The inquiry into "workability," as framed by the Court, is essentially a question of whether the Court believes itself able to continue working within a framework established by a prior decision. The unworkability of precedent provides additional incentive for the judiciary to overrule it..$^{45}$

But the converse does not necessarily follow: The mere fact of workability is not a strong argument in favor of retaining a precedent. There may exist multiple "workable" interpretations of a text, but some of them are clearly wrong. A rule that says police may search homes whenever they like, without limitation, is readily judicially administrable ("the government always wins"), as is a rule that the police may never conduct searches ("the government always loses"). But neither one is a sound interpretation of the Fourth Amendment. Workability alone should not validate either one; if a court had lapsed into either error, the fact that the erroneous ruling made for a nice, crisp, bright-line rule surely would not be a sufficient reason to adhere to it.

More to the point, to the extent that workability is a pure policy consideration-that is, a reason for adhering to or departing from a precedent apart from a belief that it is right or wrong ${ }^{46}$-it should be open to Congress to adjust that policy. At the very least, Congress must be able to direct the Court not to choose a wrong holding over a correct one on workability grounds if the correct rule is equally workable, or if a fair argument can be made that there is not an enormous difference between the two rules in terms of their workability. The Court should be obliged to say (as it surely could not, with a straight face) that resolution of a constitutional issue correctly on the merits would create such workability problems that it should be avoided in favor of retaining a more workable. but erroneous, precedent.

Indeed, in principle, it ought to be permissible for Congress to require the Court to decide a case in the manner the Court thinks correct on the merits, even if correct decision would create huge problems of judicial administrability. There are no doubt some constitutional provisions, the true meaning of which cannot be reduced to bright-line, easily administered rules that economize on judicial work. (There are probably fewer such provisions than current judicial precedent says there are, however, and there would be even fewer if the workability problems created by inconsistent precedent and doctrinal accretions were dispensed with. ${ }^{47}$ But even

45. See Planned Parenthood v. Casey, 505 U.S. 833, 854 (1992) (" [W]e may ask whether the rule has proven to be intolerable simply in defying practical workability.").

46. Of course, unworkability may also be a signal that something is amiss with the precedent decision on the merits - that is, that the precedent may be wrong.

47. See Paulsen, Enterprise, supra note 6, at 678-80. 
assuming that the Constitution yields few good, judicially administrable rules, surely Congress may legitimately decide that courts should try to reach decisions that comport with the Constitution, rather than "workable" decisions that do not.

\section{Reliance}

A more relevant-perhaps the most relevant-policy underlying stare decisis is protection of reliance interests. Traditionally, this factor is thought most apposite in the commercial context, where resources have been committed and investments have been made in reliance on a legal rule or set of rules reflected in judicial decisions. ${ }^{48}$ Had the rule been different, resources would have been committed differently. Reliance interests would seem to be at their apex when (1) the legal rule in question is well-settled and essentially uncontested within the legal regime (leading actors not to "discount" the rule in order to account for its unpredictability or instability); or (2) the legal rule is one of little intrinsic consequence aside from the fact that it has induced reliance, making it needlessly costly (and largely pointless) to seek to change it.

The classic case is a "rule of the road" that could have gone either way at time $T_{1}$ and would have been a matter of near indifference to society, but that would be hugely costly to reverse now, at time $T_{2}$, merely because a court is now persuaded that a different rule would have been better, had it occurred to the court at time $T_{1}$. Imagine, for example, the first case to decide the common-law question of whether, as two cars approach from opposite directions on a road of limited size, each driver should stay to the right or stay to the left. This (literally) rule-of-the-road situation is the paradigmatic case in which it is more important that a rule be settled than that it be settled right (or left). In fact, there is no a priori preferred answer, at least in this extreme case. As a general proposition, the greater the stability of the legal rule, the more it has led to the commitment of investment-backed expectations, and the less its intrinsic consequence, the stronger should be the policy of protecting reasonable reliance.

Even in these situations, however, such policy considerations would seem to be appropriate matters for legislative judgment. One could imagine a rational legislature serving notice that it is inappropriate for people or business entities to assume that any legal rule, subsequently thought erroneous by the court that originally decided it, will nonetheless remain

48. See, e.g., Payne v. Tennessee, 501 U.S. 808, 828 (1991) ("Considerations in favor of stare decisis are at their acme in cases involving property and contract rights, where reliance interests are involved...."). For an excellent historical treatment, see Thomas R. Lex. Stare Decisis in Historical Perspective: From the Founding Era to the Rehnquist Coun, 52 VAND. L. REV. 647, 687-703 (1999). 
operative. Indeed, it should be unnecessary to give such notice. Rational actors should rely on a decision's remaining the rule only to the extent that it can be predicted that the courts will adhere to the decision as correct. To the extent that this is uncertain, prudent businesspersons should purchase insurance against (or learn to live with) the risk of changing judicial decisions-just as they must take account of the possibility and assess the likelihood of prospective legislative enactments that might affect the value of their investments of resources (and not constitute a regulatory taking). The fact of reliance does not create a vested right in the prior legal regime; nor does it supply a basis for a court to refuse to apply a new rule of law, if that is what is otherwise required. ${ }^{49}$ Judicial decisions that are viewed by many as erroneous have an inherent instability of their own. Since even under the Court's stare decisis doctrine, cases may be overruled readily, a prudent businessperson consulting competent counsel should "discount" by some percentage his or her reliance on the judicial rule remaining stable. ${ }^{30}$

None of this, however, seems particularly relevant to the issue of abortion. The abortion issue is one of high intrinsic importance, regardless of which side one is on. It matters greatly whether the constitutional question is answered one way or another. Lives are at stake, no matter which way the question is framed. The legal issue remains (even after Casey) highly contested, and the rationale of both Roe and Casey highly controversial. While many people may have strong ideological or personal stakes in the issue being decided one way or another, there is relatively little "reliance" in the sense of the existing rule having tended to create its own reliance-having caused people to "sink costs," so to speak. There is, for example, less investment-backed social expectation in a particular legal regime concerning abortion than there was for continuation of "separate but

49. Changes in the law can hugely upset reliance interests and disappoint investment-backed expectations. Such change can occur through legislation or through revised judicial interpretation. The two should be regarded as similar, in terms of reliance interests. Given that American courts have never represented the doctrine of stare decisis to be an absolute rule of adherence to precedent, there is scarcely more reason to assume that a judicial doctrine will remain the same than there is to assume that the legislature will not change a statute. See, e.g., United States v. Carlton, 512 U.S. 26, 33 (1994) ("Although Carlton's reliance is uncontested-and the reading of the original statute on which he relied appears to have been correct-his reliance alone is insufficient to establish a constitutional violation. ... An entirely prospective change in the law may disturb the relied-upon expectations of individuals, but such a change would not be deemed therefore to be violative of due process."); Harper v. Virginia Dep't of Taxation, 509 U.S. 86, 97 (1993) ("In both civil and criminal cases, we can scarcely permit 'the substantive law [to] shift and spring' according to "the particular equities of [individual parties'] claims' of actual reliance on an old rule and of harm from a retroactive application of the new rule." (citations omitted) (alterations in original)).

50. There is thus a certain logic, even within a regime that otherwise credits the policy of stare decisis, to the argument that stare decisis should be a lesser consideration when a previous decision was made on a close vote over a "spirited dissent[ ]." Payne, 501 U.S. at 829. The need to protect reliance interests should be less because reliance should be less. 
equal" under Plessy v. Ferguson. ${ }^{51}$ In one of the most controversial passages in Casey, the Court noted that "for two decades of economic and social developments, people have organized intimate relationships and made choices that define their views of themselves and their places in society in reliance on the availability of abortion in the event that contraception should fail." ${ }^{52}$ The statement has engendered controversy on many scores-the suggestion that abortion is a method of backup birth control, the proposition that the availability of abortion helps people "define their views of themselves," the implication that the social and economic progress of women over the past several decades is in significant part attributable to the essentially unrestricted availability of legal abortion-but what seems largely to have been overlooked is a more prosaic point: what little relevance this statement has to questions of reliance in any vested, "sunk-cost" sense. It is far more true that, for "decades of economic and social developments," in vast regions of the nation, people organized personal relationships and defined their views of themselves and their places in society in reliance on the legal regime of segregation. The "reliance" argument for retaining Roe is far weaker than the reliance argument for keeping Plessy. ${ }^{53}$

The general point is simply this: To the extent that the policy of stare decisis rests on the policy of (sometimes) protecting reasonable reliance interests, Congress can weigh mere social-reliance interests and determine that they should not be given controlling weight as against correct resolution of a vitally important constitutional question by the courts. The factor of reliance seems an especially contingent one, and the policy of protecting reasonable reliance seems a particularly appropriate one for the exercise of a quintessentially legislative policy judgment. Congress should be able to decide, as a matter of legislative policy judgment, the classes of cases in which reliance interests are high and those in which they are low. The factor of reliance seems a peculiarly inapt ground for adhering to precedent on the issue of abortion-and thus especially appropriate for a

51. 163 U.S. $537,547-48(1896)$.

52. Planned Parenthood v. Casey, 505 U.S. 833. 856 (1992).

53. Cf. Paulsen \& Rosen, supra note 6, at 1293-94 (parodying Casey's stare decisis analysis by rewriting it as if it were a draft opinion of the Coun in Brown v. Board of Education reaffirming the "essential holding" of Plessy). It must be conceded that there exists a large commercial interest of abortion providers that would be affected by a change in the constitutional status of abortion. Such businesses, however, really stand in no different position than do factory owners on the day that a clean air act is passed. Casey does not make this argument for vested reliance on the part of the abortion industry: rather, the opinion makes only what might be called the "social reliance" argument, which is much more like the argument made for retaining Plessy" in 1954.

In any event, Congress could decide, in an excess of caution (whether intended seriously or ironically, as a way of highlighting the shallowness of the "reliance" policy argument in Casey). to "grandfather-in" the abrogation of stare decisis in abortion cases or delay its effective date by nine months, eliminating any argument of vested reliance on the rule's remaining the same. 
contrary legislative judgment. The fact that, in Casey's words, "people... have ordered their thinking and living around that case" 54 (whether it be Roe or Plessy) does not make the question of whether such thinking and living should be preserved, for reasons of policy alone, any less a policy determination. ${ }^{55}$

It is, emphatically, the province and duty of the legislative branch to say what policy should be followed in an area of enumerated federal government power, subject only to those restrictions specifically set forth or clearly implicit in the Constitution. ${ }^{56}$ The policy of protecting reliance on past decisions, simply because they were decided before, is not a restriction on legislative choice set forth in the Constitution. Only if a past constitutional decision is adhered to because the judges believe it is substantively correct can it be said that the judiciary is purporting to impose a limitation derived from the Constitution and not from mere policy. If Congress has power under the Necessary and Proper Clause to pass laws concerning the carrying into execution of the judicial power (as it clearly does) ${ }^{57}$ and the Constitution itself neither mandates stare decisis as a legal rule (as it clearly does not) nor grants to the judiciary an indefeasible prerogative to fashion policy-based rules of decision at variance with the Constitution and laws enacted by Congress (as it clearly does not), then Congress may decide that the protection of reliance interests is not a policy that should be pursued at the cost of correct decisions on the merits by the judiciary in accordance with the Constitution.

54. Casey, 505 U.S. at 856.

55. The case for congressional power to weigh and reject reliance interests in areas not involving vested property rights-quintessentially, social issues and issues of legal procedurc or evidence-is even easier than the general argument that Congress may decide the appropriatc weight to be given to the policy of protecting reliance interests. With social issues and procedural issues, there are no even arguably vested rights flowing from an existing legal rule and thus no issues sounding in "takings," impairment of contracts, or deprivation of "property" without due process of law. For example, a criminal defendant who makes an uncompelled confession satisfying the requirements of the Fifth Amendment but not the requirements of Miranda $v$. Arizona, 384 U.S. 436 (1966) - I am assuming for purposes of illustration that Miranda ${ }^{\circ}$ : prophylactic wamings are not constitutionally required-surely has no legitimate "reliance" interest in Miranda remaining the rule, even if he has ordered his thinking and living around that case and, consequently, expected that his un-Mirandized confession would be inadmissible.

As this Article goes to press, the Supreme Court has granted review in a case presenting an issue in certain respects analogous to the argument of this Article: If Miranda is a subconstitutional rule of judicial policy, created as a prophylactic protection of Fifth and Sixth Amendment rights, what is the scope of Congress's power to displace the Miranda rule by statute? See United States v. Dickerson, 166 F.3d 667 (4th Cir.), cert. granted, 120 S. Ct. 578 (1999).

56. I develop below the proposition that Congress has enumerated legislative power in this area below. See infra Part III.

57. See infra Section III.A. 


\section{3. "Remnant of Abandoned Doctrine"}

A third factor in Casey's treatment of the policy of stare decisis is "whether related principles of law have so far developed as to have left the old rule no more than a remnant of abandoned doctrine." 58 Put less grandiloquently: It is okay to overrule precedent if you do it in two (or more) steps. Applying that principle to abortion, the Court in Casey stated that "[n]o evolution of legal principle has left $R o e$ 's doctrinal footings weaker than they were in 1973. No development of constitutional law since the case was decided has implicitly or explicitly left Roe behind as a mere survivor of obsolete constitutional thinking." 59

Enter Washington v. Glucksberg. ${ }^{60}$ In Glucksberg, decided in 1997, the Supreme Court, unanimous as to result and with a majority of five as to the reasoning contained in Chief Justice Rehnquist's opinion for the Court, rejected a claimed substantive due process constitutional right to physicianassisted suicide. Equally significant, the Court rejected the type of substantive due process reasoning that produced Roe. ${ }^{61}$ Chief Justice Rehnquist's opinion for the Court (joined in its entirety by Justices O'Connor, Kennedy, Scalia, and Thomas), carefully read, establishes important limitations on the enterprise of judicial creation of substantive due process rights-at least any new ones (a point to which I return presently)-saying that any such claimed right must be "objectively, 'deeply rooted in this Nation's history and tradition"" and "implicit in the concept of ordered liberty." ${ }^{62}$ Furthermore, such claimed rights must be identified specifically, not with breezy generality; "careful description" of the claimed right or tradition is what is required, according to the Court in Glucksberg. ${ }^{63}$

Glucksberg has unquestionably "left Roe's doctrinal footings weaker than they were in 1973" (to quote Casey against its own continued persuasiveness in light of Glucksberg).$^{\text {ta }}$ In fact, it is no exaggeration to say that the "development of constitutional law since [Casey"] was decided has implicitly ... left Roe behind as a mere survivor of obsolete constitutional

58. Casey, 505 U.S. at 855 (citation omitted).

59. Id. at 857 .

60. 521 U.S. 702 (1997); see also Vacco v. Quill. 520 U.S. 793 (1997).

61. See Glucksberg, 521 U.S. at 720-21. For an outstanding doctrinal analysis of Glucksberg. see Michael W. McConnell, The Right To Die and the Jurispnudence of Tradition, 1997 UTAH L. REV. 665.

62. Glucksberg, 521 U.S. at 720-21 (quoting Moore v. East Cleveland, 431 U.S. 494, 503 (1977) (plurality opinion); Palko v. Connecticut, 302 U.S. 319. 325 (1937)).

63. Id. at 721 (quoting Reno v. Flores, 507 U.S. 292, 302 (1993)). The Court rejected respondents' attempt to describe the right as one of "self-sovereignty." instead choosing to frame the issue as "whether the protections of the Due Process Clause include a right to commit suicide with another's assistance." Id. at 724.

64. Casey, 505 U.S. at 857. 
thinking." ${ }^{65}$ Glucksberg does not overrule Roe, of course, and so Roe is not "explicitly" left a mere survivor of obsolete constitutional thinking. In describing the corpus of cases in which the Court had recognized substantive due process claims in the past, Glucksberg notes and quotes Casey, but artfully avoids either approval or disapproval (doubtless because the Glucksberg majority opinion comprised members of the Court on opposite sides of Casey). Glucksberg's treatment of Casey is pure description, not endorsement of a prior ruling. But it is absolutely clear that Roe could not have resulted in 1973 from the jurisprudence of substantive due process announced in Glucksberg in 1997. The abortion right was not (and still is not) "objectively, 'deeply rooted in this Nation's history and traditions," ${ }^{66}$ and that is the level of specificity-a right to abortionrequired for identification of a nontextual substantive due process liberty, not generalities like "privacy" or "personal dignity and autonomy." ${ }^{67}$ Roe cannot pass this test. Glucksberg does not announce this further conclusion, limiting itself to the case at hand. But clearly, all that is left of Roe is stare decisis. ${ }^{68}$

Indeed, Glucksberg as much as says that Casey rested entirely on stare decisis, not the merits of the substantive due process claim. Glucksberg makes the point in a footnote crisply distinguishing the Glucksberg majority's substantive due process methodology from Justice Souter's

65. Id.; see also Agostini v. Felton, 521 U.S. 203, 235-36 (1997) (" [S]tare decisis does not prevent us from overruling a previous decision where there has been a significant change in or subsequent development of our constitutional law.").

66. Glucksberg, 521 U.S. at 720-21 (quoting Moore, 431 U.S. at 503).

67. See McConnell, supra note 61 , at 671 (describing Glucksberg's language and holding). Professor McConnell notes that the "most specific level of formulation" methodology deployed in Glucksberg is essentially the position advanced by Justice Scalia in Michael H. v. Gerald D., 491 U.S. 110, 121-24 (1989), and that "[a]cceptance of this point is one of the most important aspects of the Glucksberg decision." McConnell, supra note 61, at $671 \mathrm{n} .47$.

68. In this respect, Glucksberg resembles Zobrest v. Catalina Foothills School District, 509 U.S. 1 (1993), relied on by the Court in Agostini, 521 U.S. at 223-28, as a critical case that had eroded the doctrinal foundations of the Court's Establishment Clause analysis in Aguilar $v$. Felton, 473 U.S. 402 (1985). The Court then formally overruled Aguilar in Agostini. Aguilar had struck down a program permitting publicly paid remedial math and reading teachers to provide such instruction, on-premises, at private religious schools. Zobrest, however, upheld a program permitting publicly paid sign-language interpreters to provide services to a hearing-impaired child attending a private religious school, and announced a broad principle: The neutral provision of services to public and private school students, including on-premises programs at religious private schools, does not violate the Establishment Clause. See Zobrest, 509 U.S. at 8, 13. Both the result and the principle articulated in Zobrest were logically inconsistent with the result in Aguilar. Yet the Court in Zobrest did not address the validity of Aguilar itself. Indeed, the majority opinion never so much as mentioned Aguilar. It was left for the Court in Agostini, on a motion to vacatc a continuing injunction in the Aguilar litigation itself, to formally announce that the Zobrest holding had left Aguilar a relic of past doctrine. See Agostini, 521 U.S. at 236 (quoting Casey for the proposition that "development of constitutional law since the case was decided has implicitly or explicitly left [it] behind as a mere survivor of obsolete constitutional thinking" and applying this proposition to Aguilar). Interestingly, Agostini and Glucksberg were decided within three days of each other. 
attempted reliance, in his separate opinion in Glucksberg, ${ }^{69}$ on Justice Harlan's dissent in Poe v. Ullman:

True, the Court relied on Justice Harlan's [Poe v. Ullman] dissent in Casey, 505 U.S. at 848-850, but, as [Reno v.] Flores[, 507 U.S. 292 (1993),] demonstrates, we did not in so doing jettison our established approach. Indeed, to read such a radical move into the Court's opinion in Casey would seem to fly in the face of that opinion's emphasis on stare decisis. ${ }^{70}$

This is an important statement. The Glucksberg footnote accomplishes two things simultaneously. First, it bars Justice Souter's proposed broad reading of Casey, which otherwise might have been possible given some of Casey's grandiose language concerning substantive due process. Instead, Glucksberg recognizes that any reliance in Casey on the methodological approach of Justice Harlan in Poe was aberrational, or at least not intended to be taken as anything other than a passing reference. That approach, the Glucksberg footnote says, was not consistent with the Court's "established approach" and not consistent with its judgment in Glucksberg.

Second, the Glucksberg footnote firms up what was already reasonably clear from Casey itself: The reaffirmation of Roe in Casey turned on stare decisis, not on a broad view of substantive due process that would have established Roe as correct on the merits. Justice O'Connor and Justice Kennedy, both of whom joined the opinion of the Cour in Glucksberg, apparently were not willing to go as far in Casey as Justice Souter might have gone (if his Glucksberg opinion is any indication) in bowing to substantive due process methodology and application. That may explain some of the Casey opinion's language about individual "doubts" as to the correctness of Roe as an original matter. ${ }^{71}$ For O'Connor and Kennedy, Casey was about stare decisis, not substantive due process. Glucksberg is an important clarification (or reaffirmation) of this point. O'Connor and Kennedy joined Chief Justice Rehnquist's opinion for the Court in Glucksberg, including the footnote rejecting Souter's attempted "spin" on Casey.

The thing that sustains Roe as case law-the only thing that continues to sustain it, in light of Glucksberg's apparent repudiation of its underlying methodology -is the policy of stare decisis. It is hard honestly to distinguish Glucksberg as involving, on its facts, a claimed right to physician-assisted suicide rather than to abortion ("decisions about whether

69. 521 U.S. at 752 (Souter, J., concurring in the judgment) (citing Poe v. Ullman, 367 U.S. 497, 543 (1961) (Harian, J., dissenting)).

70. Id. at $721 \mathrm{n} .17$.

71. Planned Parenthood v. Casey, 505 U.S. 833. 861 (1992) (referencing "whatever degree of personal reluctance any of us may have" for reaffirming Roe's "central holding"). 
or not to beget or bear a child"), in terms of the applicable substantive due process methodology. ${ }^{72}$

The fact that Roe's doctrinal legs have been cut from underneath it clearly affects what judicial doctrine should be, suggesting that the Court should reconsider Roe and that a major chunk of the stare decisis reasoning of Casey for reaffirming Roe is no longer persuasive (if it ever was). But in what way does the retreat in Glucksberg from the reasoning underlying Roe and Casey affect the permissibility of a congressional statute abrogating stare decisis in substantive due process cases?

The reason that the answer is not immediately clear is that, as illustrated by the example of Roe, Casey, and Glucksberg, the "remnant-ofabandoned-doctrine" aspect of Casey's stare decisis analysis is the one aspect of the doctrine that seems to have less to do with policy than with law-decision according to merits rather than a policy of adhering to precedent. This returns to the point, alluded to above, that the remnant-ofabandoned-doctrine inquiry is really just a two-step way of reconsidering the initial decision on the merits. The question of whether Precedent $A$ has been undermined by Precedent $B$ (or series of precedents $B, C, D$, and $E$ ) is another way (albeit a roundabout, convoluted way) of asking whether Precedent $A$ is right or not. The Court could as easily find, of course, in the next case presenting the issue, that Precedent $B$ (or a series including $B, C$, $D$, and $E$ ) wrongly departed from Precedent $A$ (as opposed to having legitimately undermined Precedent $A$ ) and, therefore, that it is appropriate to return to the "intrinsically sounder" doctrine of the earlier casc, Precedent $A$, to which Precedent $B$ had been unfaithful. ${ }^{73}$

72. See Casey, 505 U.S. at 857 . It is also instructive that, in Casey, the Court was confident that "courts building upon Roe" would not "be likely to hand down erroneous decisions as a consequence." Id. at 858 . However, the Ninth Circuit's en banc decision, reversed by the Court in Glucksberg, built its elaborate construct of a substantive due process right to physician-assisted suicide on the foundation of Roe and, even more explicitly, on Casey's description of substantive due process and its reaffirmation of the Roe holding. See Glucksberg, 521 U.S. at 726 (describung and rejecting the Ninth Circuit's reliance on Casey). It is precisely the clusiveness of making substantive due process distinctions of this type that led the Court in Glucksberg to announce its narrow and specific methodology for when such claims are constitutionally cognizable. To the extent adherence to Roe is not consistent with those criteria, its persistence preserves an inconsistency in substantive due process jurisprudence that surely could permit (indeed, has permitted) courts "building on Roe" to reach results not defensible under the analysis set forth in Glucksberg.

73. This is the form in which numerous judicial arguments for overruling a case purport to find a "special justification" for departing from the later precedent. This mini-genre includes arguments by Justice O'Connor, Justice Kennedy, and Justice Souter in cases shortly following Casey. See, e.g., Adarand Constructors v. Peña, 515 U.S. 200, 231-34 (1995) (part III-C of the opinion by O'Connor, J., joined by Kennedy, J.) (overruling Metro Broadcasting v. FCC. 497 U.S. 547 (1990), on the ground that Metro Broadcasting was at odds "with a prior doctrine more embracing in its scope, intrinsically sounder, and verified by experience"); Church of Lukum! Babalu Aye v. Hialeah, 508 U.S. 520, 571-75 (1993) (Souter, J., concurring in part and concurring in the judgment). 
This leaves a conundrum (or, if you prefer, a dilemma). The argument in Casey, combined with the Court's discussion of stare decisis in other cases, yields the following "rule": When earlier Precedent $A$ (or line of cases) is inconsistent with later Precedent $B$ (or line of cases), either one may be overruled. If the Court chooses to overrule Precedent $A$, it is because Precedent $B$ has undermined it; this supplies a "special justification" for departing from the policy of stare decisis (with respect to Precedent $A$ ). If the Court instead chooses to overrule Precedent $B$, it is because Precedent $B$ departed from the earlier understanding of Precedent $A$; this supplies a "special justification" for departing from the policy of stare decisis (with respect to Precedent $B$ ).

What, then, forms the basis for a choice between Precedent $A$ and Precedent $B$ ? Not stare decisis. The Court's doctrine of stare decisis says that either course may be chosen. The choice, then, is made on the basis of the Court's present understanding of which precedent is correct, under criteria quite apart from precedent. The "remnant of abandoned doctrine" inquiry is thus just a disguised inquiry into whether or not the prior decision was correct or, rather, which of two cases or lines of cases is correct. ${ }^{74}$

It follows that Congress should be able to say that, when the Court is weighing which of two inconsistent precedents or lines of precedent to follow, the Court should adhere to whichever one it concludes is correct on the merits. The "policy" of stare decisis does not truly justify one course or the other in this situation. Congress may cut to the chase and collapse the overruling two-step into a simplified one-step. To the extent that there is truly any policy at stake in the remnant-of-abandoned-doctrine factor, Congress may resolve the policy question in favor of directing the Court always to decide legal issues on their merits, independent of the policy of stare decisis. ${ }^{75}$

The earliest example of this "overruling two-step" in the U.S. Supreme Cour appears to be Gordon v. Ogden, 28 U.S. (3 Pet) 33 (1830), which overruled Wilson v. Daniel. 3 U.S. (3 Dall.) 401 (1798), because of the Cour's own intervening-and-undermining decision in Wise v. Columbian Tumpike Co., 11 U.S. (7 Cranch) 276 (1812). For discussion. see Lee, supra note 48. at $679-81$.

74. It is best not to think too hard about how Precedent $B$, in tension with Precedent $A$. came about in the first place. The only answers are ones that tend to undermine the legitimacy of stare decisis as a purported constraint on judicial decisionmaking: Precedent $B$ reached a result in tension with Precedent $A$ because the Cour, in deciding Precedent $B$, either concluded that Precedent $A$ was wrong, to the extent it might be thought to require a result contrary to the one actually reached in Precedent $B$, or did not perceive the tension. The Coun deciding Precedent $B$ either was not prepared to repudiate Precedent $A$ or did not think it necessary to do so (failing to perceive Precedent $A$ 's implications for Precedent $B$ ). Accordingly. Precedent $A$ was either distinguished or ignored, the first step on its way to becoming a "remnant of abandoned doctrine."

75. The fact that a later decision has undermined a prior one merely makes it all the more proper that one or the other, or both. be reexamined to determine which one is correct. The fact that Glucksberg has seriously undermined the doctrinal basis for Roe merely makes it all the more 


\section{Changed Facts}

The Court in Casey noted the possibility that changes in factual circumstances or assumptions could justify a departure from precedent. In its discussion of stare decisis, the Court stated that no change had occurred with respect to the factual assumptions underlying $R o e,{ }^{76}$ yet in the substantive portion of the opinion, the Court nonetheless proceeded to alter Roe's trimester framework to accommodate changed factual assumptions, medical advances, and changes in medical knowledge. ${ }^{77}$ It is difficult to see how the factor of "changed factual assumptions" supports (partial) adherence to prior case law in Casey. The factor probably is included in the Court's discussion in order to justify departures from precedent in other circumstances, notably Brown v. Board of Education ${ }^{78}$ which relied heavily on changed factual circumstances and new sociological studies to justify its (de facto) overruling of Plessy v. Ferguson. ${ }^{79}$ Any theory of stare decisis must of course justify Brown, and the Court in Casey, just a few pages later, labors mightily to distinguish Brown's overruling of precedent from Casey's declining to do so. ${ }^{80}$ The Court's inclusion of "changed facts" in the list of relevant factors does not supply an affirmative justification for adhering to Roe (the Court acknowledged that it needed to shift things around more than a little bit, redefine the "core holding" of Roe, and overrule two cases it found to be unjustified extensions of that core holding $;{ }^{81}$ it is included to set up the supposed contrast with Brown.

But having identified "changed factual assumptions" as relevant to the policy of stare decisis, the Court further confirms the propriety of Congress's deciding to abrogate such a policy. The types of "factual assumptions" discussed in Casey are not case-specific adjudicative facts but general findings quintessentially thought to be appropriate subjects for legislative fact-finding as a predicate for enacting general policies. These are social, or "legislative," facts. It is far more appropriate for Congress than for the Court to make legislative findings of fact that might be relevant to any pure policy determination that a constitutional holding should or should not be followed.

clear that there is nothing wrong with Congress's specifying that any non-constitutional policy basis for continuing to adhere to Roe be disregarded.

76. See Casey, 505 U.S. at 864 .

77. See id. at 860 (noting that viability has changed as a result of medical and technological advances from approximately 28 weeks at the time of Roe to 23 or 24 weeks at the time of Casey); see also Michael Stokes Paulsen, Medium Rare Scrutiny, 15 CONST. COMMENTARY 397. 398 n.6 (1998) (describing Casey as "creating a new standard for scrutiny of abortion regulation and overruling two prior cases, on the ground that stare decisis requires $\mathrm{it}^{\text {") }}$.

78. 347 U.S. 483,495 (1954).

79. 163 U.S. 537 (1896).

80. See Casey, 505 U.S. at $862-64$.

81. See id. at 860,864 . 
As with "workability," "reliance," and "remnant of abandoned doctrine," policy judgments concerning changed factual circumstances would seem to lie within the power of Congress, within broad bounds. Nothing in Casey would seem to suggest that the power to find legislative facts, to which constitutional rules are then applied by the courts, is outside the legitimate province of Congress. To the extent that application of the policy of stare decisis is (sometimes) thought to be justified, in part, on the premise that nothing relevant has changed factually (as well as legally), Congress surely has the power to determine that the premise is false insofar as it rests on assertions about social or legislative facts. Congress thus may essentially require the Court to reconsider the issue the next time it arises in a case or controversy, in the light of this revised understanding of social or legislative facts. With or without such an express determination, Congress has power to determine that the judicial policy of stare decisis, insofar as it rests on understandings of legislative fact, should be set aside in a particular category of cases. ${ }^{82}$

82. There is a connection here to the debate, begun in the early 1980s, over whether Congress may, pursuant to Section 5 of the Fourteenth Amendment. make legislative findings of fact that a human fetus is a "person" within medical understanding, and essentially require cours to determine whether the Fourteenth Amendment creates a right to abortion (or a right to life, to be given equal protection of the laws by every state) against this background, legislative determination of fact-a determination not foreclosed by Roe. See Stephen Galebach. A Human Life Statute, HUM. LIFE REV., Winter 1981, at 3. At least two prominent commentators in addition to Galebach have viewed such a proposal as requiring a reconsideration of Roe, without the constraints of stare decisis:

Under the most modest understanding of congressional interpretive authority [under Section 5 of the Fourteenth Amendment], the Court is not obligated to adopt, or even to defer to, Congress's interpretation. All the Court must do is undertake a reexamination of the issue with a fresh eye, without the constraints of stare decisis. The Section Five power thus can be seen, at a minimum, as a mechanism by which Congress may express its fundamental disagreement with the Court and may force the Courn to rethink its reading of the Constitution.

Michael W. McConnell, Institutions and Interpretation: A Critique of City of Bocme v. Flores, 111 HARV. L. REV. 153, 172 (1997); see also Stephen L. Canter, The Morgan "Power" and the Forced Reconsideration of Constitutional Decisions, 53 U. CHI. L. REV. 819.821 (1986) (arguing that Section 5 of the Fourteenth Amendment should be "understood as a tool that permits the Congress to use its power to enact ordinary legislation to engage the Court in a dialogue about our fundamental rights, thereby 'forcing' the Justices to take a fresh look at their own judgments"). Implicit in the analysis of these scholars is the premise that no serious constitutional issue is presented by a statute compelling reconsideration of a constitutional decision on the merits without the benefit of a substantive "push" from the doctrine of stare decisis in the direction of reaffirmation of the precedential decision. As noted earlier. Justice Souter's dissent in Boeme takes much the same view: It is improper to decide the validity of a congressional enactment that takes as its starting point an interpretation of a constitutional provision that differs from the Court's, without first reexamining the Court's earlier decision: if the doctrine of stare decisis does not preclude such reexamination, consideration of the validity of the statute requires such an approach. See City of Boerne v. Flores, 521 U.S. 507, 565-66 (Souter. J., dissenting); see also supra note 36 (setting forth Justice Souter's position).

The Section 5 power may provide an additional enumerated power justifying congressional abrogation of stare decisis in cases involving judicial decisions under the Fourteenth Amendment. even under the Court's narrow reading of that power in Boeme. I rely in this Aricle chiefly on Congress's power under the Necessary and Proper Clause as the enumerated-power basis for a 


\section{Judicial Integrity}

The fifth and final factor in Casey's stare decisis mix is perhaps best labeled "judicial integrity." The Court's discussion in Casey on this point is wide-ranging and more than a little overwrought. It includes the remarkable "tested by following" passage, ${ }^{83}$ the equally remarkable "overrule under fire" passage, ${ }^{84}$ and the truly haughty "belief in themselves" passage, in which the Court remarks that the belief of the people "in themselves [as a Nation aspiring to live in accordance with the rule of law] is not readily separable from their understanding of the Court invested with the authority to decide their constitutional cases and speak before all others for their constitutional ideals." ${ }^{85}$

This is clearly the factor about which the Justices authoring the joint opinion felt most strongly. Stripped of the high-flown rhetoric in these extravagant passages, however, the Court in Casey was simply repeating the idea, expressed in earlier cases, that stare decisis "contributes to the actual and perceived integrity of the judicial process" ${ }^{86}$ and thus promotes rule-of-law values. ${ }^{87}$ At the same time, of course, the Court's discussion of judicial integrity and its relationship to rule-of-law values is mitigated (if indeed it is not outright contradicted) by the Court's equal-and-opposite emphasis on the fact that stare decisis is neither constitutionally required nor strict in practice. Cases may be overruled. Stare decisis is a judicial

statute abrogating stare decisis. See infra Section III.A. Congress has power to make legislatıon providing for the carrying into execution of the judicial power, so long as the substance of such legislation does not violate the Constitution in some other respect (by prescribing. for example. particular results in particular cases or classes of cases, reopening final judgments, or legislatively altering judgments). A statute abrogating stare decisis would do none of these things and, at discussed above, merely changes a judicial practice that is not required by the Constitution.

83. Casey, 505 U.S. at 868 ("To all those who will be so tested by following. the Court implicitly undertakes to remain steadfast, lest in the end a price be paid for nothing.").

84. Id. at 867 " So to overrule under fire in the absence of the most compelling reason to reexamine a watershed decision would subvert the Court's legitimacy beyond any serious question.").

85. Id. at 868 . The bracketed language in the quotation comes from the Court's discussion just a few lines earlier in the opinion. One of the most revealing features of this passage is the Court's apparent holding of itself apart from and above the people. With the Court's references to "It]heir belief in themselves" being bound up in "their" reverence for a Court that decides "their" constitutional cases and speaks for "their" constitutional ideals, it is almost as if the Court thought it was interpreting a document beginning with the words "They, the People." $/ d$. See generally Paulsen, Enterprise, supra note 6, at 675 (comparing this passage in Casey to the attitudes of high priests of an alien culture in a Star Trek episode, who had mistakenly appropriated constitutional interpretation as an exclusive prerogative of a priestly class divorced from "We the People" who had ordained and established the alien race's remarkably UnitedStates-like Constitution).

86. Payne v. Tennessee, 501 U.S. 808, 827 (1991).

87. See Patterson v. McLean Credit Union, 491 U.S. 164, 172 (1989) ("The Court has sild often and with great emphasis that 'the doctrine of stare decisis is of fundamental importance to the rule of law." (qucting Welch v. Texas Dep't of Highways \& Pub. Transp., 483 U.S. 468, 494 (1987))). 
policy, not a rule of law. Though stare decisis is often said to be a policy of fundamental importance to the rule of law, it is not itself a rule of law and will yield when the situation requires it. Cases like Payne v. Tennessee ${ }^{88}$ stand as testimony to the proposition that the Court sometimes will view judicial integrity as requiring error-correction, not precedent-retention.

The real question is whether the judgment as to when one as opposed to the other should occur is an exclusively judicial function with respect to which Congress lacks any power to meddle. Is the policy judgment as to how best to advance, and how heavily to weigh, values of "actual and perceived integrity of the judicial process" and how best to strive for the "rule of law" within the legislative power of Congress? This question anticipates to some extent the discussion of Congress's power under the Necessary and Proper Clause, addressed in Part III below. But the short of it may be addressed immediately: The exclusive power of the judiciary to protect its "integrity" and to advance "the rule of law" extends to a power to refuse to acquiesce in or to further substantive violations of the Constitution committed by other branches, including a violation of the requirements of Article III, and freely to decide cases in accordance with its best understanding of the Constitution, statutes, and treaties of the United States. ${ }^{89}$ But it extends no further. The judiciary has no power to enhance public perceptions of its integrity by adopting rules of decision at variance with the Constitution, treaties, and laws of the United States. ${ }^{90}$ In Part III, I

88. 501 U.S. 808.

89. As Chief Justice Marshall declared in Marbury v. Madison, 5 U.S. ( 1 Cranch) 137 (1803),

[T] he judge's oath certainly applies in an especial manner, to [the judge's] conduct in their official character. How immoral to impose it on them, if they were to be used as the instruments, and the knowing instruments, for violating what they swear to support! Why does a judge swear to discharge his duties agreeably to the constitution of the United States, if that constitution forms no rule for his government? if it is closed upon him, and cannot be inspected by him? If such be the real state of things, this is worse than solemn mockery. To prescribe, or to take this oath. becomes equally a crime. Id. at 180 .

90. Does the notion of "separation of powers" give the judiciary an inherent constitutional power, exclusive of action by Congress, to determine what measures are necessary to protect its integrity? The argument could be fairly made that the judiciary has an implied power of selfdefense and self-regulation. But the argument cannot be pressed too far. It surely cannot be the case, for example, that such a power goes so far as to permit the courts to adopt rules of decision at variance with the Constitution, treaties, or laws of the United States, simply to further stated goals of promoting judicial autonomy, power, prestige, or even perceptions of judicial integrity (to the extent those are thought to flow from a policy of adhering, generally, to precedent). If the Constitution in fact supplies a rule of law that governs a case. the courts are obliged to put that rule above any nonconstitutional policy judgment of any branch. See id. at 177. That would include any statute, rule, or policy designed to advance goals of judicial autonomy. power. prestige, or integrity, to the extent that such statute, rule, or policy conflicted with faithful application of the Constitution.

Moreover, if courts possess an inherent power to adopt internal policies designed to promote the reality and the perception of judicial integrity, it is doubtful in the extreme whether such a nontextual power is exclusive of Congress's power under the Necessary and Proper Clause. As the Supreme Court has explained, 
set forth more comprehensively the power of Congress under the Necessary and Proper Clause to legislate in matters involving the performance of the judicial task, including several more examples of statutes regulating judicial conduct and decisionmaking and abrogating judge-made rules of policy. The "actual" integrity of the judicial process is advanced by correct interpretation and application of the Constitution on the merits-which is all that a statute abrogating stare decisis would ask the Courts to do, as best they can. The "perceived" integrity of the judicial process is advanced by principled, logical explanation of the reasons for reaching a correct decision. If the courts have no inherent power to pursue a general policy of advancing the judiciary's prestige, political capital, or esteem in the eyes of the public, apart from proper performance of their functions under Article III, surely Congress has the power to direct them not to do so, especially when such a policy would result in the improper performance of their constitutional responsibilities. To the extent that the doctrine of stare decisis is attributable to the policy of furthering public perceptions of the integrity of the judicial process, and given that it is a policy judgment whether that value is furthered by following erroneous precedent rather than correcting it, Congress has the power to determine that "judicial integrity" values are better served by requiring courts to decide cases solely on the basis of what the Court believes are correct rules of law supplied by the Constitution, statutes, and treaties of the United States. Indeed, given that the policy of stare decisis as formulated and applied by courts sometimes permits courts to overrule cases and sometimes leads courts to reaffirm precedents, the correctness of which they openly profess to doubt, surely Congress could make the judgment that a flat rule that the policy of stare decisis should never dictate or determine a result in a case involving federal

The constitution concludes its enumeration of granted powers, with a clause authorizing Congress to make all laws which shall be necessary and proper for carrying into execution the foregoing powers, and all other powers vested by this constitution in the government of the United States, or in any department or officer thereof. The judicial department is invested with jurisdiction in certain specified cases, in all of which it has power to render judgment.

That a power to make laws for carrying into execution all the judgments which the judicial department has power to pronounce, is expressly conferred by this clause. seems to be one of those plain propositions which reasoning cannot render plainer.

Wayman v. Southard, 23 U.S. (10 Wheat.) 1, 22 (1825) (mem.).

Indeed, Congress has passed a number of laws for the purposes of promoting "judicial integrity," and the courts have rejected constitutional challenges to them predicated on separationof-powers objections (among others). See, e.g., Hastings v. Judicial Conference of the United States, 829 F.2d 91 (D.C. Cir. 1987) (upholding against constitutional challenge the Judicial Councils Reform and Judicial Conduct and Disability Act of 1980); In re Certain Complaints Under Investigation by an Investigating Committee of the Judicial Council of the Eleventh Circuit, 783 F.2d 1488 (11th Cir. 1986) (rejecting a challenge to a judicial-misconduct investigation by the Eleventh Circuit pursuant to the same act). 
law would better serve public purposes of promoting respect for the judiciary and for the rule of law. ${ }^{91}$

The essential, narrow point is that the Constitution does not confer upon the judiciary an exclusive power to decide cases on the basis of mere policy considerations about how its decisions will affect public perceptions of judicial integrity. Nor does the Constitution contain or justify a rule that the judiciary has exclusive constitutional power to adopt whatever practices, procedures, or decision principles it feels will best enhance public perceptions of the judiciary's integrity. If legislative power otherwise exists to prescribe different rules and Congress has exercised its power to do so, the judiciary's rules must give way.

It is that last "if"--does legislative power exist in this area at all?- that is the subject of Part III. The point of this Part has been that nothing in Casey or in any other judicial exposition of the doctrine of stare decisis establishes the doctrine as anything other than a rule of policy and practice. If rules of judicial policy or practice are otherwise within the enumerated legislative powers of Congress to enact or modify, Congress may alter the judiciary's policy in this regard.

\section{CONGRESS AND STARE DECISIS}

\section{A. The Necessary and Proper Clause Power with Respect to the Judicial Process}

The Necessary and Proper Clause of the Constitution gives Congress power " $[\mathrm{t}] \mathrm{o}$ make all Laws which shall be necessary and proper for carrying into Execution the foregoing Powers, and all other Powers vested by this Constitution in the Government of the United States, or in any Department or Officer thereof." 92 This is the power that enables Congress to create rules of procedure and evidence (or to delegate such powers to an appropriate body) and to alter judicially created default rules on such matters. Even if it is assumed that, in the absence of congressional action, the judiciary is not barred from creating its own rules of procedure, evidence, practice, policy, and administration, the Necessary and Proper Clause certainly empowers Congress to displace such rules if it so chooses, within a broad range of allowable choice..$^{93}$

91. I address below the question whether Congress could choose the opposite rule-that is, mandate stare decisis in constitutional cases-and conclude that it could not. See infra notes 161165 and accompanying text.

92. U.S. CONST. art. I, $\$ 8, \mathrm{cl} .18$.

93. The Supreme Court has long conceded that the Necessary and Proper Clause power of Congress reaches such matters. See Wayman, 23 U.S. (10 Wheat) at $21-22$ ("That a power to make laws for carrying into execution all the judgments which the judicial department has power to pronounce, is expressly conferred by [the Necessary and Proper Clause], seems to be one of 
There are two limitations on this power. First, implicit in the Necessary and Proper Clause itself is a separation-of-powers principle that Congress may not pass executory laws (that is, laws for the carrying into execution of other powers or functions of the government) that infringe on the autonomous constitutional powers of other branches. ${ }^{94}$ Thus, if the correct interpretation of the Constitution is that the President possesses a plenary power to veto legislation for whatever reason he chooses, Congress may not by statute limit the grounds upon which the President may veto bills. (If it did so, the President should ignore the statute in deciding whether to issue a veto and, of course, refuse to enforce as law what Congress believes became "law" because of an "ineffective" veto. Likewise, the courts should refuse to give legal effect to such a statute. $)^{95}$ Such a law is not constitutionally "proper." So, too, a statute requiring federal courts to reach specified outcomes in individual adjudications would be unconstitutional, if the correct interpretation of Article III is that the courts have autonomous constitutional power to apply general rules of law to specific cases. Such a statute would not be a "proper" means for carrying into execution the judicial power, whatever Congress's view of its necessity or desirability.

I will develop the content of Article III's limitations on Congress's exercise of the Necessary and Proper Clause power with respect to judicial matters in just a moment, after noting the second limitation on the Necessary and Proper Clause power to enact laws for carrying into execution the powers of the executive or judicial departments: Congress may not pass executory laws that are themselves substantively unconstitutional in some other, collateral respect-that is, that are unconstitutional for reasons other than interference with an exclusive constitutional prerogative or power of a coordinate branch. ${ }^{96}$ For example, Congress could not pass a statute violating the Free Speech Clause or Free Exercise Clause rights of federal employees, even if the law were otherwise an appropriate provision for carrying into execution the powers of the executive branch (that is, if it did not violate some aspect of Article II). Nor could Congress pass a statute requiring that federal judges not hire law clerks of a given race, if the correct interpretation of the Constitution prohibits racial discrimination by instrumentalities of the federal

those plain propositions which reasoning cannot render plainer. The terms of the clause neither require nor admit of elucidation."); see also infra Section III.C (providing and discussing examples of such congressional rulemaking).

94. I owe this insight to the scholarship of Gary Lawson and Patricia Granger. See Gary Lawson \& Patricia B. Granger, The "Proper" Scope of Federal Power: A Jurisdictional Interpretation of the Sweeping Clause, 43 DUKE L.J. 267 (1993).

95. See generally Michael Stokes Paulsen, The Most Dangerous Branch: Executive Power To Say What the Law Is, 83 GEO. L.J. 217 (1994) (defending the propriety of autonomous coordinate interpretive power of the three departments of the national government).

96. See Lawson \& Granger, supra note 94 , at 271. 
government, ${ }^{97}$ even if it would not violate Article III to regulate the judiciary's employment practices generally. One can view executory laws that violate the Constitution's separation of powers-that is, statutes infringing on some exclusive constitutional province of another branchmerely as one species of unconstitutional enactments. It is helpful, however, to distinguish between laws that are unconstitutional because they intrude on the province of another branch and laws substantively unconstitutional on other grounds, wholly collateral to any separation-ofpowers concern. ${ }^{98}$

The fact that stare decisis is not constitutionally required means that the second type of possible objection is not in play. The analysis of Part II should establish this point: A statute abrogating stare decisis does not violate any substantive provision of the Constitution, because nothing in the Constitution mandates stare decisis, in either a strong or weak form. ${ }^{99}$ Thus, if a statute abrogating stare decisis is to be thought unconstitutional, it can only be on the theory that the decision whether to pursue the various policies underlying the doctrine of stare decisis, and the corollary decision of how far to pursue such policies in any given case, lie within the exclusive province of the Article III judiciary as part of the case-deciding function entrusted exclusively to that department. Put somewhat differently, the argument against the constitutionality of a statute abrogating stare decisis would have to be that the constitutional province of the judiciary embraced by "[t]he judicial Power" of Article III entails an entirely autonomous, constitutional power (that is, one immune from congressional adjustment under the Necessary and Proper Clause) to determine the weight to be given precedent-including erroneous precedent-in subsequent

97. See, e.g., Adarand Constructors v. Peña. 515 U.S. 200 (1995) (applying strict scrutiny to race-based government affirmative-action programs).

98. The Supreme Cour has made a similar distinction in its cases analyzing the spending power. In addition to criteria setting forth intrinsic limitations on Congress's spending power to attach substantive conditions to receipt of federal grants (to be a valid exercise of the spending power, the requirement must be in pursuit of the general welfare, must be clearly stated, and must not be unrelated to the federal interest in paricular national projects or programs), there is the extrinsic limitation that the substantive condition on the grant not violate some other constitutional provision that independently bars the substance of the condition. See South Dakota v. Dole, 483 U.S. 203 (1987). Noninterference with an exclusive province or privilege of another branch is an intrinsic limitation on the scope of Congress's Necessary and Proper Clause power to enact executory laws; not violating some other constitutional provision that independenuly bars the substance of the enactment is an extrinsic limitation on the scope of the power.

99. Abrogation of stare decisis would not violate the Due Process Clause just because it might upset some reliance interests. There is no vested legal right of individuals in a particular precedent remaining the governing judicial interpretation, any more than there is a vested legal right of individuals in a particular statutory regime. See United States v. Carlton. 512 U.S. 26, 3334 (1994) ("An entirely prospective change in the law may disturb the relied-upon expectations of individuals, but such a change would not be deemed therefore to be violative of due process."); Harper v. Virginia Dep't of Taxation, 509 U.S. 86, 97 (1993) (holding that reliance interests do not justify selective refusal to apply new judicial interpretations of the law to events that preceded the new interpretation); see also supra note 49. 
constitutional adjudication, in order to advance policy considerations not themselves of constitutional stature. On this view, the judiciary has not only "the province... to say what the law is," ${ }^{100}$ but also the sole and exclusive power to determine the extent to which its own decisions should themselves be treated as binding law, even if erroneous.

\section{B. Does "[t]he Judicial Power" Entail an Autonomous Constitutional Power of Courts To Prescribe a Doctrine of Stare Decisis?}

The proposition that the judiciary has sole and exclusive power to determine the stare decisis weight to be accorded its own decisions does not sound absurd-at least not quite. Indeed, as formulated, it sounds fairly debatable. No doubt, many readers instinctively will leap (or have already leapt) to this conclusion. Upon examination, however, the intuition breaks down almost immediately, the arguments in its favor being surprisingly weak. Without exaggeration, nothing in the text, history, or structure of the Constitution-nothing even in judicial precedents interpreting the Constitution-supports the proposition that the judiciary possesses an exclusive constitutional power, unalterable by act of Congress, to prescribe a doctrine of stare decisis that (sometimes) accords decision-altering weight to prior judicial precedent, whether or not erroneous.

"The judicial Power" of Article III simply does not include a plenary constitutional power, or inviolable institutional privilege, to make what are concededly rules of policy - albeit rules of judicial policy-that prevail over rules of law set forth in the Constitution or lawful federal statutes and treaties. Any claim to the contrary, in addition to contradicting virtually everything the courts have ever said about congressional power and judicial power, would have almost absurd implications for much of present practice, casting doubt upon heretofore unchallenged congressional power to prescribe rules of evidence, rules of procedure, rules of decision, rules of claim and issue preclusion and recognition of judgments, standards of judicial or appellate review of administrative and judicial decisions, choiceof-law rules, and statutes abrogating prudential standing. As a matter not only of textual meaning and historical understanding, but also of current doctrine-both judicial doctrine and practices so widely accepted they have never been the subject of serious legal challenge-the argument that Congress lacks constitutional authority to abrogate the judicial policy of stare decisis is simply unsustainable. As unfamiliar and bracing as the argument for congressional power to abrogate stare decisis may be, the arguments in favor of such a power are more persuasive, by several orders of magnitude, than the arguments for (and implications of) a plenary and 
absolute constitutional power of the judicial branch to prescribe rules of judicial policy that prevail over contrary federal law, including the Constitution.

\section{Text}

Begin with the text of Article III. Nowhere does the text specify that " $[t]$ he judicial Power" includes the power to vest precedent with authoritative, decision-altering weight, independent of its persuasiveness. No one, to my knowledge, has offered a serious textual argument to such effect.

It is worth pausing for a moment to let this point sink in. There is little more to be said about this simple and obvious point, yet it has tremendous significance: The constitutional text simply cannot be read to support the assertion of a plenary judicial power to vest precedent with quasi-legislative force, effectively altering the meaning of the Constitution's commands for purposes of judicial interpretation in subsequent cases. There is no Stare Decisis Clause in the Constitution. Nor is there a Stare Decisis Power granted to the judiciary. Indeed, it is extremely hard to come up with even a barely plausible, straight-faced textual argument for such a proposition-so hard that no one has ever really tried to do so. The text itself simply does not support such a claim.

\section{History}

Historical evidence of the original meaning of " $t$ the judicial Power" evidence of the original intentions of the Framers, or of the original understanding of the ratifying conventions-fails to support such a claim either. So far as I have been able to discover, no such claim (or accusation) was ever made by anyone in the Constitutional Convention; nor by any prominent (or even obscure) framer or ratifier at the time of the drafting, debate over, and early implementation of the Constitution; nor even by any prominent opponent in the ratification debates or Anti-Federalist literature. The most that any proponent of the Constitution was prepared to say was that uncertainties and ambiguities left open by the Constitution might come to be settled, in practice, by practice. ${ }^{101}$ Alexander Hamilton, writing in The

101. In retirement, Madison explained this viewpoint as a matter of legislative and political "stare decisis," in order to justify his decision as President in 1817 to accept a congressional power to charter a national bank that he had rejected as unconstitutional as a Congressman in 1791. Letter from James Madison to Charles Jared Ingersoll (June 25, 1831), in THE MIND OF THE FOUNDER: SOURCES OF THE POLITICAL ThOUGHT OF JAMES MADISON 390, $390-93$ (Marvin Meyers ed., rev. ed. 1981). Madison develops the analogy of judges acquiescing in "solemnly repeated and regularly observed" judicial precedents with which they disagree as an argument for a similar rule in legislative deliberations. Id. at 392. Interestingly, however, Madison does not 
Federalist No. 78, provides the most authoritative, contemporaneous exposition of the meaning of "[t]he judicial Power," and notes the desirability and inevitability of a system of precedent, but Hamilton did not claim that the judicial power embraces the power to prescribe binding precedential effect for judicial decisions on matters of federal law irrespective of the correctness of such decisions. ${ }^{102}$ Hamilton had much to say about the judicial power, brilliantly defending judicial review and judicial independence, and explicating the jurisdiction and authority of the judiciary in The Federalist Nos. 78-83. Nowhere, however, does he claim for the federal judiciary an autonomous province to vest controlling authority in precedents irrespective of the soundness of their reasoning or the correctness of their results.

The passage of The Federalist that comes closest to such a proposition comes near the end of No. 78, where Hamilton defends life tenure as appropriate in part because of the nature of the qualifications required for a federal judge-knowledge and understanding of the "voluminous code of laws" that is a necessary "inconvenience[]... connected with the advantages of a free government" 103 -and the need to attract the few persons who would be sufficiently competent in their study and understanding of them. In the next sentence, Hamilton mentions precedent:

To avoid an arbitrary discretion in the courts, it is indispensable that they should be bound down by strict rules and precedents, which serve to define and point out their duty in every particular case that comes before them; and it will readily be conceived from the variety of controversies which grow out of the folly and wickedness of mankind, that the records of those precedents must unavoidably swell to a very considerable bulk, and must demand long and laborious study to acquire a competent knowledge of them. ${ }^{104}$

As Professor Thomas Lee has written, "Viewed in isolation, Hamilton's side-bar on precedent might be construed to conceive of a strict

argue that the issue was settled by $M c C$ ulloch $v$. Maryland, 17 U.S. (4 Wheat.) 316 (1819), which offered the judicial rule on the question of the bank's constitutionality. The occasion for writing this letter, Madison notes, was Andrew Jackson's veto on constitutional grounds of the bill to recharter the Second Bank of the United States, but Madison used the opportunity to explain his own decision as President not to veto the bank bill presented to him in 1817, two years before McCulloch was decided. See Letter from James Madison to Charles Jared Ingersoll, supra, at 390. It is, of course, also possible that Madison was simply trying his best to reconcile an inconsistency in his own political or constitutional beliefs and conduct, rather than admit to constitutional crror on one or the other occasion.

102. See ThE FEDERALIST No. 78, at 398-99 (Alexander Hamilton) (Gary Wills ed., 1982).

103. Id.

104. Id. 
rule demanding adherence to precedent under all circumstances." 105 However, Professor Lee continues,

Federalist No. 78 was hardly conceived as a comprehensive exposition of the doctrine of stare decisis, and Hamilton's statement of a prima facie rule of adherence to precedent should not be construed to exclude the existence of exceptions or countervailing considerations. Hamilton's conception of a judge's duty was to follow not only precedent, but "strict rules," which seems to be a reference to the lamentable "voluminous code of laws... necessarily connected with the advantages of a free government." In combination, strict rules and precedents may define the court's duty, but a suggestion that every case would be predetermined by the authority of case law alone would have been specious. Nor is it clear that Hamilton was discussing the question of whether the Supreme Court would have the power to overrule its own decisions; Federalist No. 78 may simply have been addressing a rule of vertical stare decisis requiring lower federal courts to follow case law from a superior tribunal. ${ }^{106}$

Professor Lee's analysis is probably a sufficient response to any attempt to overread Hamilton as stating a strict rule of stare decisis. I would add several further points because of the importance of Hamilton's views, expressed in The Federalist, as evidence of the probable understanding of the meaning of " $[t]$ he judicial Power" under the Constitution, at the time of its adoption. First, this passage of The Federalist No. 78 is fully consistent with a conclusion that precedent serves primarily an "information" function rather than a "disposition" function. ${ }^{107}$ The thrust of Hamilton's discussion is that judges will need to be familiar with lots of statutes and lots of cases, that this mastery can be expected of only relatively few men, and that it is important that the job of federal judge contain sufficiently attractive features to assure that such men (and, today, women) will serve in such posts-a point that still has salience today. A statute abrogating stare decisis would not avoid the need for judges to consult precedent, since precedent would continue to serve a valuable information function and supply a baseline against which to evaluate a proposed alternative interpretation of the law.

Second, Hamilton is not in this passage explicating the meaning of "[t]he judicial Power" of Article III. He is defending the idea of life tenure by pointing to the practice that might be expected of federal judges

105. Lee, supra note 48 , at 663 .

106. Id. at $663-64$.

107. See supra text accompanying notes $26-29$ (discussing the difference between these two conceptions of the role of precedent). 
interpreting the Constitution and laws of the nation. There is a difference between the content of a legal rule (here, the meaning of "[ $t]$ he judicial Power") and expectations concerning practice under that rule. ${ }^{108}$ Hamilton is not explaining what the Constitution means about the judicial power, but describing what he expects judges will do-study and consider precedents, as well as the "voluminous code of laws"-and that description is consistent (as noted above) with the information function of precedent.

Third, Professor Lee understates considerably the crucial point that Hamilton could not possibly have meant by this discussion that precedents-especially precedents contrary to the laws being interpretedwould be literally binding on judges in the future, that is, that the habit of consulting precedent was anything other than a rule of practice and policy. As the entirety of Professor Lee's article makes clear, such a conception of precedent has never existed in American law and certainly was not part of the common legal culture of Hamilton's day. Thus, in context, Hamilton's statement that judges must be "bound down by strict rules and precedents" cannot plausibly be read as advocating the view that " $t$ ] he judicial Power" under the Constitution itself is of such a nature as to require judges to follow precedent.

Fourth, if the Constitution itself does not prescribe a particular doctrine concerning the weight to be given prior precedent (and such a reading of The Federalist No. 78 would stretch Hamilton's words much too far, as just discussed), absolutely nothing in The Federalist No. 78 can be read as vesting in the judiciary a constitutional power, exclusive of the legislature, to create such a doctrine as an incident of carrying into execution its power to decide cases and, moreover, to give that doctrine controlling or decisionaltering weight in the actual decision of cases. Moreover, such an inference would be flatly inconsistent with Hamilton's clear exposition of Congress's Necessary and Proper Clause power. Hamilton acknowledges the Clause to be sweeping, both as a general proposition ${ }^{109}$ and, most significantly, as applied to the judicial power: In The Federalist No. 81, Hamilton unequivocally embraces a congressional power to prescribe that the Supreme Court could not reexamine facts found by juries (under the preSeventh Amendment Constitution that Hamilton was defending) in classes of cases where Congress determines that the jury trial right should apply, a position consistent with legislative power in the areas of judicial practice

108. Elsewhere, I have written that this difference explains the correctness of Brown v. Board of Education, 347 U.S. 483 (1954), notwithstanding historical evidence of the expectation of some advocates of the Fourteenth Amendment that it would not have the effect of invalidating de jure segregation. See Paulsen, supra note 95, at 227 n.23; see also Richard H. Fallon, Jr., A Constructivist Coherence Theory of Constitutional Interpretation, 100 HARV. L. REV. 1189, $1199,1272-82$ (1987) (making a similar argument).

109. See THE FEDERALIST No. 33, supra note 102, at 155-59 (Alexander Hamilton). 
and procedure and inconsistent with an exclusive judicial prerogative over such matters. ${ }^{110}$

Finally, for Hamilton to have claimed such authority for the proposed federal judiciary would have been to provide powerful ammunition for the Constitution's opponents. Specifically, it would have armed Publius's principal antagonist in the discussion over the scope of the judicial power, the Anti-Federalist writer Brutus, with even better arguments than he had against the judiciary. Brutus, to whom Hamilton was responding more or less directly in The Federalist No. 78, said many disparaging things about the judicial power and its supposed uncontrollable nature."' But not even Brutus argued that courts would possess a power to dictate that future courts be bound by precedents, even when they thought them erroneous; he argued only that courts would seize upon expansive precedents to further expand their own powers, that expansive construction of national powers would increase the power of the national courts, and that such decisions in favor of expansive national power would come to define the practical boundaries for, and exercise of, the legislative power. ${ }^{12}$ Brutus did not say that expansive precedents would preclude narrower judicial interpretations in the future, but only that this was not what was likely to occur. Brutus's whole point was that the federal courts would essentially feel free to decide legal issues however they liked, and that this was likely to result in abuses and in concentration of power in the national government generally. ${ }^{113}$ If

\section{As Hamilton said:}

The legislature of the United States would certainly have full power to provide that in appeals to the Supreme Court there should be no re-examination of facts where they had been tried in the original causes by juries. This would certainly be an authorised exception; but if for the reason already intimated it should be thought 100 extensive, it might be qualified with a limitation to such causes only as are determinable at common law in that mode of trial.

THE FEDERALIST No. 81, supra note 102, at 416 (Alexander Hamilton).

111. Ironically, the assertion that the judicial power entails judicial supremacy, as opposed to simply a coordinate power of judicial review, was first made by Brutus as an argument against the Constitution, and was never made by the Constitution's backers. See BRUTUS No. XI (Jan. 31 . 1788), reprinted in 2 THE COMPLETE ANTI-FEDERALIST 417, 417-22 (Herbert J. Storing ed., 1981) (asserting that the Constitution creates a regime of unchecked judicial supremacy over the other branches of federal government); BRUTUS NO. XV (Mar. 20, 1788), supra, at 438, 438-41 (same). Hamilton vigorously denied the charge in The Federalist No. 78. See GARRY WILLS, EXPLAINING AMERICA: THE FEDERALIST 126-36 (1981); Paulsen, supra note 95, at 245-52.

112. BRUTUS No. XI, supra note 111, at 417, 420; BRUTUS No. XII. supra note 111 , at 422 . 423-25.

113. See BRUTUS No. XI, supra note 111, at 417, 420-22: BRUTUS No. XII, supra note 111, at 422, 423-24; BRUTUS No. XV, supra note 111 , at 437, 441. Brutus envisioned that courts would build upon precedents in expanding their powers. See BRUTUS NO. XV, supra note 111, at 437, 441 ("[O]ne adjudication [on the meaning of the Constitution] will form a precedent to the next, and this to a following one."). But Brutus's discussion makes it clear that he considered the use of "precedent" in this sense to be one of enabling further departures from a strict reading of the central government's powers, not one of constraining or limiting judicial power (as opposed to determining the bounds of Congress's legislative power, see BRUTUS NO. XII. supra note 111, at 422, 423). The closest Brutus comes to asserting a power of precedent to bind future judicial interpretations is his claim that "[t]he opinions of the supreme court, whatever they may be, will 
"[t]he judicial Power" of Article III had been susceptible at the time of the understanding, and thus to the charge, that headstrong judges could generate decisions that, even if clearly wrong, would stand as precedents binding on future judges, with subsequent judicial departure from or corrections of such precedents sharply limited or precluded entirely, one could have expected Brutus to level the charge, which would have fit perfectly with his attack on the dangerously oligarchic judiciary. But Brutus did not offer any such point. Precedent could become the foundation and plausible pretext for a slow and steady accretion of judicial power and national power at the expense of the states and the rights of individuals. But the ratchet, for Brutus, works in one direction only: Precedent does not limit what courts might do in the future, but merely provides a plausible pretext for further departures from the text.

In short, the available historical evidence tends to show that the argument for an autonomous judicial power to assign binding precedential weight to their decisions was not within the contemplation of the framing generation, and was not a subject of serious discussion at the time of the Constitution's adoption. No one ever said that the Constitution, correctly interpreted, implied that judicial precedents legitimately could have the effect, or that federal judges legitimately would possess the autonomous power, of binding future federal judges, absolutely or to some degree, to adhere to past decisions, whether or not subsequently viewed as erroneous. No one ever claimed (or charged) that judicial decisions could entrench erroneous decisions or legitimately have the effect of requiring subsequent courts to follow precedents that they believed were erroneous. Neither Madison nor Hamilton nor any other prominent framer made such a claim for the judicial power. Neither Brutus nor any other prominent opponent

\footnotetext{
have the force of law; because there is no power provided in the constitution, that can correct their errors, or controul their adjudications. From this court there is no appeal." BRUTUS NO. XI, supra note 111 , at 417,420 . In context, Brutus is claiming that Supreme Court opinions (evidently meaning decisions, not "opinions" literally) will bind other branches, and all other courts. Just a sentence earlier, however, he argued that the Supreme Court would not be bound by "any fixed or established rules," but rather "will determine, according to what appears to them, the reason and spirit of the constitution." Id. Hamilton's remark, in The Federalist No. 78, that "[t]o avoid an arbitrary discretion in the courts, it is indispensable that they should be bound down by strict rules and precedents, which serve to define and point out their duty in every particular case that comes before them" - and thus that life tenure is necessary to attract the caliber of persons who have endured the "long and laborious study" necessary to perform the task of judging competentlyappears to be designed as a direct rebuttal to Brutus, cleverly presented as a passing observation on an uncontroversial point. See THE FEDERALIST No. 78, supra note 102, at 399 (Alexander Hamilton). But if the indirect assertion is being made by anyone that the Supreme Court's own prior precedents will literally bind the Court in its later decisions, it is Hamilton's assertion, not Brutus's (and, as noted above, that does not appear in fact to be Hamilton's assertion). Nor does it appear that any other prominent Anti-Federalist writer ever made the claim that the judicial power included an autonomous power to determine the binding effect of precedent. Cf. Lec, supra note 48, at $663 \mathrm{n} .79$ (noting that Anti-Federalist commentary focused on the Supreme Court's general powers in equity to circumvent any binding force of law).
} 
leveled such an accusation against it; their argument was that courts would always feel free to reach whatever results they wanted.

It remains theoretically possible that such a power in the courts was one of the well-understood background assumptions of the common law, against which the Framers might be thought to have been drafting, and went unspoken because all assumed it to be true. Aside from the obvious hazards of predicating a reading of the Constitution on an argument from historical and textual silence, the proposition appears simply to be untrue. As Professor Thomas Lee's recent scholarship shows, the historical evidence cannot support such an understanding of stare decisis at common law. The picture that emerges is one in which precedent is treated as evidence of the content of the law, but not as law itself. ${ }^{1 / 4}$ Precedent was not binding on the courts. Moreover, the common law was always subject to alteration by the legislature. That fact undermines any claim that the common-law understanding of " $[t]$ he judicial Power" included a power to prescribe binding prospective force to judicial decisions, with such force unalterable by the legislature. To be sure, the idea of a written Constitution, enforceable by courts as law superior to mere legislative enactments, distinguishes stare decisis in constitutional law from stare decisis as a common-law doctrine; the fact that legislative power existed to derogate from the common law does not itself imply a legislative power to abrogate stare decisis in constitutional adjudication. But that is at least half the point: Even if a power to assign quasi-legislative effect to precedents were thought to be an aspect of the common-law power of courts, that power was always subject to legislative alteration; and if the Constitution is thought to have imported accepted common-law understandings into the term "[t]he judicial Power," it is a dubious move indeed to say that a common-law judicial power to accord prospective force to precedents, subject to legislative alteration, became an absolute and exclusive judicial power to accord prospective force to precedent in constitutional cases, immune from legislative alteration, without anyone having said so. It is difficult to claim-at least without any supporting historical evidence-that the Constitution simultaneously adopted the common-law understanding of the power of courts to prescribe a binding doctrine of precedent, incorporated that understanding into the power of constitutional review of legislative acts by courts, and removed the common law power of the legislature to enact statutes changing the common-law. At the very least, the burden should be on anyone asserting such a view to justify it in terms of the available

114. See Lee, supra note 48, at 665-66. Professor Lee's thorough and compelling historical analysis shows the extremely weak historical basis for any claim that the founding generation understood "[t]he judicial Power" to entail a plenary constitutional power of courts to prescribe binding precedential effect for their decisions. 
historical evidence, and the available historical evidence does not support such a position.

The argument for an autonomous power of the judiciary to vest in precedent some binding effect on future judicial decisions is a relative latecomer. At best, it can trace its roots to Joseph Story's 1833 Commentaries on the Constitution of the United States. ${ }^{115}$ More realistically, the view appears to be an outgrowth of late-twentieth-century assertions of judicial supremacy generally. ${ }^{116}$ If such an argument existed at all at the time of the framing, it apparently was not within the mainstream of legal and constitutional thought at the time. It certainly was not a notable part of the debate over the meaning and consequences of " $[t]$ he judicial Power" to be created by adoption of the proposed Constitution.

\section{Constitutional Structure}

If neither text nor history supplies good evidence for an autonomous power of courts to prescribe a binding doctrine of stare decisis, what about constitutional structure? The argument for a structural inference of such a power is somewhat more promising (though obviously weakened by the absence of direct textual or historical support). The argument would go something like this: ${ }^{117}$ Article III judges necessarily have autonomous power to decide cases properly before them, and this power necessarily

115. The idea that "[t]he judicial Power" establishes precedents as binding law, obligatory in future cases, appears to have been an early-nineteenth-century innovation, perhaps presaged by certain Marshall Court opinions. See id. at 666-81. In 1833, Justice Story boldly, and without supporting evidence, asserted it to have been the original understanding of the Framers. See 1 JOSEPH STORY, COMMENTARIES ON THE CONSTITUTION OF THE UNITED STATES $\$ 378$ (Fred B. Rothman \& Co. 1991) (1833) ("[T]his conclusive effect of judicial adjudications, was in the full view of the framers of the constitution."). But even Story's position does not appear to be that "[t]he judicial Power" implies an autonomous prerogative on the part of courts to create $"$ doctrine of precedent and thereby vest their decisions with controlling or decision-altering weight in subsequent cases. Rather, Story's argument appears to have been that the decisions of the highest courts of a jurisdiction in fact establish the law and bind future courts' interpretations, and that interpretation of the Constitution is governed by the same rule; that is, that the Constitution itself incorporates a rule of stare decisis. This extreme view-that the Constitution requires adherence to judicial precedent-has never been the accepted view in American constitutional law. On Story's overreaching view of the judicial power generally, see Paulsen, supra note 95. at 311-20.

116. See, e.g., Cooper v. Aaron, 358 U.S. 1, 18-19 (1958) (equating Supreme Court decisions interpreting the Constitution with the Constitution itself, as the supreme law of the land); see also. e.g., United States v. Nixon, 418 U.S. 683, 704-05 (1974) (similar). See generally Michael Stokes Paulsen, Nixon Now: The Courts and the Presidency After Twenty-Five Years, 83 MINN. L. REv. $1337,1339 \mathrm{n} .10,1346-48$ (1999) (noting the evolution of judicial assertions of judicial supremacy since 1950, culminating in Nixon).

117. Although I have not seen this argument made directly in any judicial opinion or academic literature, I cannot confidently assert that it has never been made in some form similar to that offered in the text. My formulation of the best possible structural argument for a judicial power to prescribe binding force to precedent flows from conversations with, or written comments of, Bill Kelley, Gary Lawson, Henry Monaghan, Chip Lupu, and Tom Lee. 
implies an autonomous power of law-interpretation. To be sure, the courts must exercise that law-interpreting power in accordance with the Constitution, statutes, and treaties of the United States. Precedents admittedly do not have that same status: A judicial precedent may not literally alter the content of the Constitution, statutes, or treaties of the United States. But the judiciary surely must have the power to treat precedents, where they exist, as evidence of the best understanding of these provisions, and thus must have the penumbral power to erect second-order rules for how to treat such evidence of what the law is and the weight of contrary evidence that must exist before such precedential evidence is disregarded. At a minimum, the judiciary surely has power to adopt such an evidentiary approach to law-interpreting in the absence of congressional action.

The next step in the structural argument is the tough one: explaining why that power must be an exclusive one. The argument might proceed as follows: A congressional power to prescribe rules constraining whether or when the judiciary may accord some degree of outcome-altering weight to its own prior decisions would come perilously close to interfering with the core constitutional power of the courts-that of rendering autonomous judgment on questions of law presented-by limiting the second-order "evidentiary rules" that courts may devise as a means of exercising that power. Put differently, the power to decide cases and the power to interpret the law in the course of deciding cases together imply a penumbral structural autonomy of the judiciary to devise second-order "evidence-ofwhat-the-law-is" rules as a means for carrying out the power to decide and interpret. To accept a congressional power to interfere with such rules would be to threaten the core of the judicial power to decide "what the law is" by overly impairing the ancillary power of the judiciary to decide how to decide "what the law is." In a system where an evident concern of the Framers, well-expressed in Hamilton's Federalist papers defending the independence of the judiciary, was that the political branches would be too strong and tend to overawe the judiciary, ${ }^{118}$ one might reasonably conclude that the general principles of separation of powers and an independent judiciary support the structural inference that this ancillary power of the judiciary-the power to decide how to decide-must be wholly exempt from congressional regulation. ${ }^{119}$

118. See THE FEDERALIST No. 78, supra note 102, at 394 (Alexander Hamilton) ("[T] he judiciary is beyond comparison the weakest of three deparments of power ... and ... all possible care is requisite to enable it to defend itself against [the legislative and executive departments'] attacks.").

119. An analogy to the executive power also helps the structural argument. at least rhetorically: Could Congress prescribe, pursuant to the Necessary and Proper Clause, the methodology the President must use in deciding whether to prosecute individuals for federal crimes? Could Congress prescribe, for example, that the executive branch prosecute an equal 
This is true (the argument continues) even if it means that the judiciary thus cannot be prevented from elevating certain policy considerations that it values (stability, regularity, protection of reliance, advancement of perceptions of judicial integrity) above its present understanding of the meaning of the Constitution, statutes, and treaties of the United States. It helps the argument that these policies are so widely believed to be important "rule-of-law" values, and thus seem like reasonable, familiar, and perhaps appropriate considerations to put ahead of the judiciary's firstbest present understanding of what the law is. It also helps that the judiciary's willingness to put aside its best present understanding of the Constitution sounds like an act of humility-deferring to the wisdom of the past instead of being arrogantly confident of the correctness of its own present interpretation. To be sure (the argument would concede), this view might make the judiciary ultimately uncontrollable in the policies it develops and implements for carrying out its law-interpreting functions, but such a result surely is more consistent with separation-of-powers notions than is the idea that Congress can control, to a significant degree, the way that the courts go about their business of deciding cases. The courts, not Congress, get to decide how to decide, including what weight to accord past judicial interpretations as evidence of what the law is.

proportion of crack cocaine and powder cocaine possession or distribution offenses? If the executive power over law-execution entails a power to decide how to engage in such lawexecution, does not the judicial power of law-interpretation similarly entail a power to decide how to engage in law-interpretation?

The analogy is a powerful one, suggesting that congressional power must exist in both cases or neither. The validity of the analogy, however, may turn on the distinct nature of the law. executing executive power and the case-deciding judicial power and what is entailed within each. The law-executing power may simply be different in kind. If the power to execute the laws itself entails an executive prerogative of enforcement discretion-some degree of autonomous control over how, against whom, when, and (more problematically) perhaps even whether, a law will be enforced, see Nixon, 418 U.S. at 693 ("[T] Executive Branch has exclusive authority and absolute discretion to decide whether to prosecute a case ...."); United States v. Cox. 342 F.2d 167, 171 (5th Cir. 1965) (en banc)-then the hypothetical analogous statute would be unconstitutional because of the distinctive content of "[t]he executive Power" of Article II, and would provide no analogy for questions of Congress's Necessary and Proper Clause powers with respect to "[t]he judicial Power" of Article III. Similarly, a statute prescribing standards for granting pardons or vetoing bills might violate the President's constitutional powers, if such powers are purely discretionary in nature. Mercy can be arbitrary in a way that law-interpretation cannot. The nature of many executive powers is that they can be exercised in accordance with the executive's will: Stat pro ratione voluntas. The nature of law, however, is to be constrained by rules.

A tighter analogy would be a statute directing the President not to follow a particular interpretation of a statute or constitutional provision simply because that was the interpretation of his predecessor. Such a statute would not be unconstitutional, because it does not deprive the President of his independent power to interpret the law; it would merely tell him that he is not to be artificially restricted in its exercise. The statute does not interfere with any discretionary power of the President. On the scope of the power of executive law-interpretation generally, compare Paulsen, supra note 95, with Gary Lawson \& Christopher D. Moore. The Executive Power of Constitutional Interpretation, 81 IOWA L. REV. 1267 (1996). 
The structural argument is amenable to the sympathetic presentation I have just offered, but it suffers from some serious flaws. First, the specter of the uncontrollable judiciary-free to substitute policies of its own choice for what it otherwise would be bound to conclude is the policy dictated by the Constitution, federal statutes, and federal treaties-cannot be dismissed so easily. If the basis of the argument is a supposed structural inference from the Constitution's system of separation of powers, its toleration of an uncheckable judicial power to prescribe rules at variance with the Constitution is fundamentally at odds with the regime of separation of powers that is thought to yield it. Nothing is clearer from the Framers' discussion of separation of powers under the Constitution than their categorical opposition to the effective concentration of powers in a single institution, uncheckable by the others, with power to act directly on individuals and institutions and to compel the acquiescence of the other two branches of government. ${ }^{120}$ When an asserted "structural" constitutional argument generates a conclusion at odds with the Constitution's most fundamental structural postulate, something is amiss. That is the case with the asserted structural inference of an uncheckable judicial prerogative to prescribe a doctrine of precedent that gives precedent decision-altering weight in opposition to the judiciary's best understanding of what the law is. It is important to be clear as to just what such an argument entails, in order to evaluate the soundness of its reasoning: The argument claims the existence of penumbral judicial powers to prescribe rules of policy that trump the rules of law that the courts would otherwise find to be contained in the Constitution, statutes, and treaties of the United States. Unless the argument is that the Constitution dictates a specific doctrine of stare decisis-and neither the courts nor any credible scholar has ever made such a claim, to my knowledge-the claim would have to be that the judiciary is constitutionally empowered to devise one of its own choosing, without limitation, by virtue of Article III's grant of "[t]he judicial Power" and the idea of separation of powers generally. That is pushing penumbras too far

120. See, e.g., THE FEDERALIST No. 47, supra note 102, at 244 (James Madison) (noting that accumulation of powers in the same hands "may justly be pronounced the very definition of tyranny" and that a constitutional provision for "accumulation of power or ... a mixture of powers having a dangerous tendency to such an accumulation" would be a decisive argument for "reprobation of the system"); THE FEDERALIST NO. 48, supra note 102. at 250 (James Madison) ("[N]one of [the departments] ought to possess directly or indireclly, an overuling influence over the others in the administration of their respective powers. It will not be denied, that power is of an encroaching nature, and that it ought to be effectually restrained from passing the limits assigned to it."); THE FEDERALIST NO. 51, supra note 102, at 261 (James Madison) (stating that the remedy to problem of concentration of power is to "so contriv[e] the interior structure of the government, as that its several constituent parts may, by their mutual relations, be the means of keeping each other in their proper places"). For a general treatment, with more extensive discussion of the historical evidence, see Paulsen, supra note 95, at 228-62. 
and misusing the idea of separation of powers. ${ }^{121}$ It is a classic lawyer's trick-and an especially easy trick to play with separation-of-powers structural arguments - to take a text, series of texts, or asserted relationship between texts, discern some "principle" within it (formulated at a sufficiently high level of generality), and then read that principle back into the Constitution, sometimes in flat opposition to specific textual provisions or clear structural principles, and apply the new principle as if it stated a rule of law. The argument that I have sketched for an autonomous judicial power to prescribe binding rules concerning precedent is of this type: It relies on amorphous "separation of powers" principles and "independence of the judiciary" principles, unmoored to the specific constitutional provisions from which these principles are said to derive, and then extrapolates from those principles to a new "rule" that cannot be said with any confidence actually to be present in the text. This game is common in constitutional law generally, but it seems one to which "structural" separation-of-powers arguments are particularly susceptible.

In sum, "[t]he judicial Power" of Article III simply does not include a plenary constitutional power, or inviolable institutional privilege, to make rules of policy - even rules of judicial policy - that prevail over rules of law set forth in the Constitution (or lawful federal statutes and treaties). And stare decisis is such a rule of policy. In this respect, stare decisis is not notably different from rules of "prudential standing" or other judge-made rules of procedure, practice, custom, restraint, or comity that Congress may change by statute.

\section{C. "Precedents" for Congressional Power in Matters of Judicial Practice}

That brings us to a second major problem with the "structural" argument that judicial independence implies a plenary power of the judiciary (immune from congressional alteration) to devise second-order rules governing how the judiciary goes about the process of deciding cases

121. A brief aside is appropriate concerning the use and misuse of "structural" constitutional arguments. It is sloppy nomenclature, and often simply sloppy thinking, to say that a statute is unconstitutional "because it violates the Constitution's separation of powers." Often the assertion is pure conclusion. The Constitution creates a system of separate and interdependent branches with different powers and checks on each other. A statute might violate a rule implicit in the structure and logic of Article I, a rule implicit in the structure and logic of Article II, a rule implicit in the structure and logic of Article III, or even a rule fairly deducible from the fact that each branch derives its enumerated powers directly from the Constitution rather than from one of the other branches. (The argument for judicial review, in The Federalist No. 78 and Marbury $v$. Madison, 5 U.S. (1 Cranch) 137, 175-80 (1803), is the classic example of an argument of this last type, inferring from the independence of the branches that the Court need not regard Congress's interpretation of the Constitution as controlling the Court's.) But these are all species of textual arguments. There is no freestanding "Separation of Powers Clause" that contains its own statuteinvalidating set of rules or standards; there is only the collection of texts that make up the system. 
and controversies: If that claim were true, it would be radically inconsistent with longstanding and current practice, repeatedly reaffirmed and embraced by all three branches of government since the earliest days of the Republic. This fact alone does not itself make the structural argument unsound; it could be that dozens of past and present statutes are, and always have been, unconstitutional. But it does place an extremely heavy burden of persuasion on the structural argument for a plenary judicial power over precedent-a burden made doubly heavy by the irony that it requires making an argument for an exclusive judicial power over precedent that is contrary to so much historical and judicial precedent.

It might be countered that abrogating stare decisis is itself inconsistent with long-accepted constitutional practice within the courts. But the tradition of relying on precedent, it must constantly be recalled, is not one of constitutional stature. By the judiciary's own admission, it is a mere rule of policy. The question on the table, therefore, is whether that traditional policy may be altered by legislative act. To be sure, a statute abrogating stare decisis would be an innovative application of Congress's Necessary and Proper Clause power with respect to the carrying into execution of the judicial power of Article III. But novelty does not equal unconstitutionality. The fact that a proposal might be new does not remotely begin to prove that it is unconstitutional. ${ }^{122}$ It might be simply an unexplored avenue that is perfectly permissible under the Constitution. And while this specific proposal may be, in a narrow sense, "unprecedented," there have been numerous other statutes regulating judicial policy, practice, and rules of decision, including many that date back to the First Congress and that have long been accepted as legitimate. A statute abrogating stare decisis would not be hugely different from these. ${ }^{123}$

122. But cf. Romer v. Evans, 517 U.S. 620, 633 (1996) (implying that the exceptional or unusual nature of a law may be a factor contributing to its unconstitutionality under the Equal Protection Clause).

123. All of this assumes that the Supreme Court has been right all along in stating that the doctrine of stare decisis is a rule of policy, not a command of the Constitution. Of course, the Court could have been wrong in saying so, and simply repeated the error dozens of times. If so, that should not give the error special status. Repetition of erroneous analysis concerning the constitutional status of precedent would no more make that analysis sound than reperition of any other erroneous constitutional doctrine turns error into truth. The thesis of this Article, after all, is that Congress may require the Court to decide constitutional issues on the merits, without the thumb of precedent on the scale. The same premise necessary to the constitutionality of such a proposal-that precedents do not themselves possess constitutional status, and do not literally control subsequent constitutional interpretation-suggests, paradoxically, that the Court legitimately may revisit that constitutional premise. Were the Court to conclude, contrary to nearly all its earlier statements on the point, that some rule of stare decisis is commanded by the Constitution, it would follow that the Court should hold, consistent with that view, that Congress may not tamper with that constitutional rule.

But to continue the paradox, such a ruling would confirm the premises of this Aricle: Prior judicial doctrine is not itself of constitutional status. If upon reconsideration of the merits of a constitutional issue the Court is persuaded that the prior doctrine is unsound, it may alter or abandon it. If that is true, stare decisis is simply a rule of judicial policy, not a rule of 
A few examples suffice to make the point. First, the Rules of Decision Act $^{124}$ (originally section 34 of the Judiciary Act of 1789) prescribes a choice-of-law rule detailing what federal courts may and may not regard as law-sources for rules for deciding cases-in certain categories of cases falling within federal jurisdiction. The federal courts are forbidden from relying on legal rules of their own creation, rather than on state law, in cases where the federal Constitution, statutes, and treaties do not apply. So, too, a statute abrogating stare decisis would forbid federal courts from relying on legal rules of their own creation, rather than on the Constitution, in cases in which the Constitution applied and the courts concluded that the precedents depart from a proper understanding of the Constitution. If " $[t]$ he judicial Power" entails an immunity from congressional regulation affecting the sources of "law" to which a federal court may look in deciding cases within its jurisdiction, the Rules of Decision Act would be no less vulnerable than a statute abrogating stare decisis.

Second, the Full Faith and Credit Act ${ }^{125}$ (originally enacted in 1790) ${ }^{126}$ prescribes the preclusive effect that federal courts must give to prior state proceedings, again dictating what shall and shall not constitute controlling law (indeed, dictating results where the rule of the statute applies) in a category of cases falling within federal court jurisdiction. If Congress may prescribe the res judicata effect to be accorded certain prior decisions in certain categories of cases, might it not likewise prescribe the stare decisis effect to be accorded prior decisions? ${ }^{127}$

constitutional law. And if that is true, the policy of stare decisis should fall within the province of Congress under the Necessary and Proper Clause. Thus, if the Court is right that the doctrine of stare decisis is a mere rule of policy, Congress may adjust the policy. And if the Court is wrong about that-if some rule of stare decisis is implicit in the Constitution itself-the Court can reach such a conclusion only by violating such a rule of stare decisis with respect to the question of the constitutional status of stare decisis!

124. 28 U.S.C. $\$ 1652$ (1994) ("The laws of the several states, except where the Constitution or treaties of the United States or Acts of Congress otherwise require or provide, shall be regarded as rules of decision in civil actions in the courts of the United States, in cases where they apply.").

125. Id. $\$ 1738$ ("The records and judicial proceedings of any court of any... State. Territory or Possession ... shall be proved or admired in other courts within the United States and its Territories and Possessions. ... Such Acts, records and judicial proceedings ... shall have the same full faith and credit in every court within the United States . . . as they have by law or usage in the courts of such State, Territory or Possession from which they are taken.").

126. See Act of May 26, 1790, ch. 11, 1 Stat. 122.

127. A more difficult question might be presented were Congress to abolish the doctrine of res judicata. The law of judgments may (or may not) be of constitutional dimension in the eyes of the Supreme Court. The Court has not said. Cases like Parklane Hosiery Co. v. Shore, 439 U.S. 322 (1979), tend to suggest that, at least in some respects, the law of judgments is judicially created common law. In any event, it is clear that the Court has said that stare decisis (which is readily distinguishable from res judicata) is a doctrine of policy and practice only, not one of constitutional dimension.

It also seems clear that at least some legislation altering what might otherwise be the judicial default rule for deciding the res judicata effect of a prior judicial decree is well accepted in practice. For example, Federal Rule of Civil Procedure $60(\mathrm{~b})$, adopted pursuant to delegated congressional power under the Rules Enabling Act, is, in form, a direct regulation of judicial 
Third, the Anti-Injunction Act ${ }^{128}$ (originally enacted by Congress in 1793) prohibits federal courts from enjoining state judicial proceedings except when explicitly authorized by an act of Congress or when necessary in aid of their jurisdiction or to protect or effectuate their judgments. This is a direct limitation on the exercise of the federal judicial power. ${ }^{129}$ Indeed, Congress's recognized authority to direct and control the exercise of courts' equitable discretion furnishes a direct analogy to a statute abrogating stare decisis. If Congress "may intervene and guide or control the exercise of the courts' discretion" to issue traditional equitable remedies, as the Supreme Court has said, ${ }^{130}$ Congress equally "may intervene and guide or control" courts' exercise of any purely discretionary power of the judiciary. If stare decisis is a doctrine of discretion, or policy, it is hard to distinguish Congress's authority to direct and control its exercise from Congress's recognized authority over courts' power to issue equitable remedies.

Fourth, perhaps the most direct analogy to a statute abrogating stare decisis is Congress's accepted power to abrogate judge-made prudential standing limitations on the exercise of federal judicial power. In three very recent cases, the Supreme Court has held, without recorded dissent on the point, that Congress may enact legislation that displaces such nonconstitutional or quasi-constitutional judicial policy-a policy, like stare decisis, predicated on perceived traditional considerations of judicial restraint. ${ }^{131}$ In 1997, in Raines v. Byrd, ${ }^{132}$ the Court noted that Congress

practice concerning res judicata, prescribing rules binding on the judiciary concerning when final judgments may be reopened. In Plaut v. Spendthrift Farm, 514 U.S. 211 (1995), the Supreme Cour treated Rule 60(b) as one that "merely reflects and confirms the courts" own inherent and discretionary power." Id. at 233-34. Such a reading, unnecessary to the judgment in Plaut (Rule 60 (b) is far different from a statute commanding the reopening of a judgment in a specific case. the issue presented by Plaut) seems in tension with some of the language of the Rule itself. Such a reading is also in tension with the Court's debate in Agostini v. Felton over whether or not the Court's action was consistent with the text of Rule 60(b). Compare Agostini v. Felton, 521 U.S. 203, 214-17, 234-40 (1997), with id. at 255-60 (Ginsburg. J., dissenting). This debate seems somewhat discordant with the notion that the Rule is mercly a recitation of courts" "inherent and discretionary power," to use Plaut's words. Plaut. 514 U.S. at 234. Neither the majority nor the dissenters in Agostini cited Plaut's characterization of Rule 60(b).

128. 28 U.S.C. $\S 2283$.

129. The limitation is well recognized. See, e.g., Parsons Stecl v. First Ala. Bank, 474 U.S. 518 (1986). The Supreme Court has recognized the converse as well: Congress may remove the traditional equitable discretion of courts to decline to issue injunctions. See, e.g.. Veinberger v. Romero-Barcelo, 456 U.S. 305, 313 (1982) ("Congress may intervene and guide or control the exercise of the courts' discretion...." (emphasis added)): TVA v. Hill. 437 U.S. 153, 187-88 (1978). Congress has thus been recognized as possessing the power to mandate or withhold a particular form of traditional judicial relief and to override customary judicial practice to the contrary.

130. Weinberger, 456 U.S. at 313.

131. See Bennett v. Spear, 520 U.S. 154, 162 (1997) (“'T]hese "judicially self-imposed limits [prudential standing rules] on the exercise of federal jurisdiction, '... are founded in concern about the proper-and properly limited-role of the cours in a democratic society. . . .; but unlike their constitutional counterparts, they can be modified or abrogated by Congress ...." (citations omitted)).

132. 521 U.S. 811 (1997). 
possesses power to "eliminate[] any prudential standing limitations" on federal courts' exercise of the judicial power, simply by creating a cause of action. ${ }^{133}$ That same year, in Bennett $v$. Spear, ${ }^{134}$ the Court unanimously concluded that Congress had done exactly that in the citizen-suit provisions of the Endangered Species Act, stating explicitly that prudential standing limitations "can be modified or abrogated by Congress." ${ }^{135}$ In 1998, in Federal Election Commission v. Akins, ${ }^{136}$ the Court again applied this rule, finding that Congress had eliminated prudential standing limitations in a category of cases. ${ }^{137}$

It would seem to follow from Raines, Bennett, and Akins that Congress possesses power to abrogate the judicial policy of prudential standing limitations whenever Congress wishes to do so. Just as the Court has rightly distinguished between those elements of standing doctrine that flow from Article III, which Congress may not abrogate, and those that are merely judicial policies of self-restraint or self-limitation that Congress may displace, ${ }^{138}$ so, too, a crisp distinction exists between the inviolable Article III judicial power to decide the merits of a legal dispute and the judicial policy of stare decisis, which Congress may displace. If stare decisis is not a doctrine of constitutional status, but a mere judicial policy (as the Supreme Court has so often said), there is no basis for distinguishing congressional power to abrogate stare decisis from congressional power to abrogate prudential standing limitations. ${ }^{139}$

133. Id. at 820 n.3.

134. 520 U.S. 154.

135. Id. at 162 .

136. 524 U.S. 11 (1998)

137. See id. at 20. It had long been assumed that Congress possessed such authority. See, e.g., Association of Data Processing Serv. Orgs. v. Camp, 397 U.S. 150, 154 (1970) ("Congress can, of course, resolve the question one way or another, save as the requirements of Article III dictate otherwise.") It has likewise been taken for granted that non-constitutionally based judicial abstention doctrines may be abrogated by congressional statute. See, e.g., Rex E. Lee \& Richard G. Wilkins, An Analysis of Supplemental Jurisdiction and Abstention with Recommendations for Legislative Action, 1990 BYU L. REV. 321, 361.

138. See Raines, 521 U.S. at 820 n.3.

139. The closeness of the doctrinal analogy between prudential standing and stare decisis is fairly remarkable. In language strikingly similar to its description of the doctrine of stare decisis, the Court has characterized prudential standing as a doctrine that is "part of judicial selfgovernment," Lujan v. Defenders of Wildlife, 504 U.S. 555, 560 (1992)-indeed, a "rule of judicial self-governance" that is "closely related to Article III concerns." Warth v. Seldin, 422 U.S. 490, 509 (1975) (emphasis added). It is a doctrine that embodies "self-imposed restraints on the exercise of judicial power," United States Parole Comm'n v. Geraghty, 445 U.S. 388, 410 (1980), the content of which is "to be shaped by the decisions of the courts as a matter of sound judicial policy," Asarco Inc. v. Kadish, 490 U.S. 605, 613 (1989). The language used by the Court to characterize the doctrine of prudential standing is so similar to the language used to describe the doctrine of stare decisis that, were one to read the above-quoted texts, without attribution, to someone conversant with constitutional law and ask him or her to name the doctrine described, "stare decisis" is probably as likely a response as "prudential standing." If a "rule of judicial self-governance" embodying "self-imposed restraints on the exercise of judicial power" that are "shaped by the decisions of the courts as a matter of sound judicial policy" and "founded in concern about the proper ... role of the courts," Bennett, 520 U.S. at 162 (citations omitted), is 
There is still more: What are the Federal Rules of Evidence (and other sets of procedural rules) if not a direct regulation, pursuant to Congress's power under the Necessary and Proper Clause, of how the judiciary goes about its business of deciding cases? ${ }^{140}$ The Rules Enabling Act of $1934^{141}$ (which had its much earlier ancestors) exercised congressional power over judicial matters of procedure and practice. Its arrangements explicitly contemplate congressional trumping of judge-made procedural rules, and even congressional repudiation of judge-made proposed rules. Congress has made use of this authority-directly regulating the adjudicative process. ${ }^{1.2}$ If the judiciary has complete constitutional autonomy to decide how to decide cases and controversies, including the (penumbral) power to prescribe second-order rules with the force of law, immune from congressional revision, as to how the courts will carry out their core function of deciding cases, then the Federal Rules of Evidence, the Federal Rules of Civil Procedure, the Federal Rules of Appellate Procedure, the Federal Rules of Criminal Procedure, and-the grandfather of all this error-the Rules Enabling Act are all unconstitutional. Indeed, the Federal Rules of Evidence would be the most flagrant violation imaginable of such a constitutional principle. As Judge Easterbrook has argued, "[I] the process of adjudication really is independent of legislative control, all procedural rules predating the Rules Enabling Act of 1936-and all statutes overriding rules promulgated by judges under that law-must be unconstitutional too." 143

nonetheless one that is "subject to the control of Congress," Asarco, 490 U.S. at 613, and thus "can be modified or abrogated by Congress," Bennett, 520 U.S. at 162, it is hard to claim a constitutional immunity for the similariy described doctrine of stare decisis, which is "a principle of policy," e.g., Seminole Tribe v. Florida, 517 U.S. 44, 63 (1996); Helvering v. Hallock. 309 U.S. 106, 119 (1940), a "policy judgment," Agostini v. Felton, 521 U.S. 203, 235 (1997), and "informed by a series of prudential and pragmatic considerations," Planned Parenthood v. Casey, 505 U.S. 833, 854 (1992), from the power of Congress to modify or abrogate such a malter of judicial policy pursuant to its Necessary and Proper Clause legislative power.

140. Like the Federal Rules of Civil Procedure, the Federal Rules of Evidence are enacted pursuant to delegated congressional power, under a lawmaking process specified in the Rules Enabling Act, 28 U.S.C. $\$ \$ 2071-2074$ (1994). To be sure, the Supreme Court plays a role in the rulemaking process, but its role is dictated by statute and its proposed rules are subject to revision. repeal, and amendment by Congress. In a very real sense, then, every one of the Federal Rules of Evidence is enacted pursuant to the legislative power of Congress under the Necessary and Proper Clause, not pursuant to the judiciary's own constitutional powers.

141. Id.

142. See, for example, FED. R. EVID. 704(b), which was added by Congress as part of the Insanity Defense Reform Act of 1984, Pub. L. No. 98-473, $\$ 406,98$ Stat. 1837, 2067-68; and FED R. EvID. 413-415, which was enacted by Congress as part of the Violent Crime Control and Law Enforcement Act of 1994, Pub. L. No. 103-322. § 320935(a). 108 Stat. 1796, 2136-37. See also 18 U.S.C. $\S 17$ (1994) (assigning to criminal defendant the burden of proving the affimative defense of insanity, and requiring such proof by clear and convincing evidence).

143. French v. Duckworth, 178 F.3d 437, 450 (7th Cir.) (Easterbrook, J., dissenting from the denial of rehearing en banc), cert. granted, $120 \mathrm{~S}$. C. 578 (1999). Duckworth is one of many cases currently pending in the lower federal courts challenging various aspects of the Prison Litigation Reform Act of 1996, 18 U.S.C.A. $\$ 3626$ (West Supp. 1999). The Supreme Court's 
One might attempt to distinguish rules for proving facts from rules for "proving the law" 144 - the policy of stare decisis being, at most, a "rule" imposing a higher burden of proof for propositions of law when a prior case stands opposed to that proposition. But it is not clear what principled ground would support such a distinction. Deciding questions of fact and deciding questions of law are both part of the core judicial function of deciding cases and controversies. If Congress may legislate how courts decide what the facts are, it is hard to see why Congress may not legislate how courts decide what the law is. So long as the interpretive evidence-ofwhat-the-law-is rule chosen by Congress lies within the fair range of choices admitted by the broad concept of due process of law (just as the Federal Rules of Evidence do, for evidence-of-fact questions), and so long as the interpretive rule prescribed does not in its substance violate the Constitution in some other respect, it is difficult to conceive of a principled constitutional objection that would not ensnare the Federal Rules of Evidence (and of Civil Procedure, and of Appellate Procedure) as well. If stare decisis is conceived of as a second-order judicial rule of evidence-ofwhat-the-law-is (establishing a rebuttable presumption in favor of past judicial interpretation), then a statute abrogating stare decisis would simply remove any such heightened burden of proof for propositions of law-a classic evidence rule.

There are examples of Congress doing essentially this very thing. Congress has legislated rules concerning not only the degree of deference courts must give to findings of fact made by other decisionmakers, but also the degree of deference to be given to conclusions of law. As to facts: Consider Federal Rule of Civil Procedure 52, directing appellate courts to affirm factual findings of district courts unless clearly erroneous. ${ }^{1.5}$ Consider also the truly huge number of statutes directing courts to affirm decisions of administrative agencies if the agencies' actions are supported by substantial evidence in the record. ${ }^{146}$ As to law: The Freedom of Information Act (to pick just one example) directs that courts review agency conclusions of law de novo; the courts are instructed not to be bound by a prior legal judgment (albeit one of an agency, not an earlier

decision in Duckworth may provide further indirect support for the legitimacy of a statute abrogating stare decisis.

144. For a fascinating discussion of "proving the law," see Gary Lawson, Proving the Law. 86 Nw. U. L. REV. 859 (1992).

145. See FED. R. CIV. P. 52(a) ("Findings of fact, whether based on oral or documentary evidence, shall not be set aside unless clearly erroneous, and due regard shall be given to the opportunity of the trial court to judge of the credibility of the witnesses.").

146. See, e.g., Administrative Procedure Act, 5 U.S.C. $\S 706(2)(e)$ (1994) (directing the reviewing court to set aside certain agency actions, findings, and conclusions, if it finds them to be "unsupported by substantial evidence"). 
court). ${ }^{147}$ The once-perennial debate in administrative law over the so-called "Bumpers Amendment," a proposal that would require courts to engage in non-deferential judicial review of agency interpretations of law-which would abrogate the judicial interpretive rule of Chevron, U.S.A. v. Natural Resources Defense Council, ${ }^{148}$ under which agency interpretations of statutes are given special deference-has taken for granted that Congress has the constitutional power to abrogate such a judicial policy of deference. The entire debate has been over the merits of the statute on policy grounds-would it be a good thing? No one has suggested that the Bumpers Amendment would violate the judicial power of Article III by purporting to alter a judicial rule of statutory interpretation, yet that is exactly what it does. ${ }^{149}$

Finally, there are legislatively mandated rules for the disqualification of individual federal judges from sitting on and deciding certain matters. ${ }^{150}$ If Article III prohibits any and all legislative acts that regulate how the courts go about the business of hearing and deciding cases, these statutes regulating the integrity of the judicial process would also be unconstitutional. ${ }^{151}$

The doctrinal evidence is practically overwhelming: rules of procedure; rules of evidence; statutes prescribing the res judicata effect to be accorded judgments of other courts; statutes prescribing the level of deference to be accorded to findings of fact by other courts; statutes prescribing the level of deference to be accorded to conclusions of law by administrative agencies; statutes prescribing choice-of-law rules and rules of decision; statutes mandating or forbidding traditional equitable remedies; and statutes abrogating judicially developed rules of prudential standing. For a cour to assert, and by holding maintain, that a statute abrogating stare decisis is an unconstitutional interference with the judicial power would cast very serious doubt on the legality of all of these longstanding, accepted statutes carrying into execution the federal judicial power under the Necessary and Proper Clause. Such a view is not impossible, and might even be

147. See Freedom of Information Act, 5 U.S.C. $\$ 552(a)(4)(B)$ (“'On complaint ... the cour shall determine the matter de novo. . . . and the burden is on the agency to sustain its actions.").

148. 467 U.S. 837 (1984).

149. For a general discussion of the Bumpers Amendment. see, for example. STEPHEN G. BREYER \& RICHARD B. STEWART, ADMINISTRATIVE LAW AND REgULATORY POLICY 319 (3d ed. 1992); Ronald M. Levin, Review of "Jurisdictional" Issues Under the Bumpers Amendment, 1983 DUKE L.J. 355; Ronald M. Levin, Scope of Review Legislation: The Lessons of 1995, 31 WAKE FOREST L. REV. 647 (1996). Justice Scalia, in an article commenting on the Chevron doctrine, has suggested fairly clearly that Congress could abrogate the doctrine by statute, either for a particular administrative statute or wholesale. See Antonin Scalia. Judicial Deference to Administrative Interpretations of Law, 1989 DUKE L.J. 511, 515-16 (assuming that Congress could specify a rule of non-deference to agency interpretations of law).

150. See 28 U.S.C. \$144 (1994); id. \$ 455.

151. See French v. Duckworth, 178 F.3d 437, 450 (7th Cir.) (Easterbrook. J., dissenting from the denial of rehearing en banc), cert. granted, $120 \mathrm{~S}$. Ct. 578 (1999). 
maintained in good faith. ${ }^{152}$ But such an assertion would be a truly extraordinary challenge to congressional power and (oddly enough, if the issue provoking such an assertion was the policy of stare decisis) an extraordinary departure from settled law and longstanding practice, dating to the earliest days of the nation and repeatedly reaffirmed by the Supreme Court.

If these other applications of Congress's legislative power under the Necessary and Proper Clause are accepted as valid, it becomes almost impossible to avoid the conclusion that Congress has constitutional power to abrogate the judicial policy of stare decisis. If Congress may do all these things and legitimately expect federal courts to adhere to these commands, then Congress likewise may abrogate the judicial policy of stare decisis and expect courts to honor that policy choice.

\section{Necessary and Proper Limits}

Just how far can Congress go, then, in legislating on matters of judicial process implicating the judicial decisonmaking function? Can Congress, under the rubric of passing laws for the "carrying into execution" of the judicial power essentially control the exercise of the judicial power? Could Congress forbid the writing of concurrences? Dissents? Forbid citation to prior opinions? Require a supermajority vote of the Supreme Court to strike down an act of Congress?

A full examination of this wonderful line of questions lies beyond the scope of this article. ${ }^{153} \mathrm{My}$ proposition here is more discrete: Whatever the outer limits of Congress's legislative power under the Necessary and Proper Clause with respect to the judiciary-under any fair conception of that power that coheres with the Constitution's text, structure, and history, and with historical practice and precedent concerning that power-a statute abrogating stare decisis does not even begin to approach those limits. At a minimum, the Necessary and Proper Clause permits Congress to proscribe any procedure or practice of courts that impairs the faithful exercise of

152. See David E. Engdahl, Intrinsic Limits of Congress' Power Regarding the Judicial Branch, 1999 BYU L. REV. 75, 158-74. Professor Engdahl challenges some of these longstanding and long-accepted doctrines but readily concedes that he is an outlier on such matters. See id. at 79. One may accept Professor Engdahl's general formulation about lack of congressional power to legislate in ways that impair "judicial potency"-the actual power of the judiciary entailed in "[t]he judicial Power" that Article III assigns to the courts alone-and yet disagree (as I do) with all of his applications of that formulation that would invalidate longstanding and long-accepted congressional regulations of the judiciary. Those disagreements would take me far afield from my purpose here. It is sufficient here to note that Engdahl's conclusions would invalidate a great deal of existing statutory law regulating judicial structure and conduct.

153. For important recent contributions to the literature addressing these questions, see $i d$; and Martin H. Redish, Federal Judicial Independence: Constitutional and Political Perspectives. 46 MERCER L. REV. 697 (1995). 
"[t]he judicial Power" and to prescribe rules and procedures conducive to the faithful exercise of that power. This certainly includes power to abrogate any judicial procedure or practice that puts policy considerations ahead of what otherwise would be the judiciary's first-best legal interpretation of the Constitution. ${ }^{154}$

It is important in this regard to emphasize what a statute abrogating stare decisis would not do, in order to make clear why such a statute is a "proper" executory law under the Necessary and Proper Clause-one that does not violate the judicial power created by Article III. First, such a statue would not forbid consideration of precedent for its persuasive value. The statute would simply withdraw from courts any power to accord decisional weight to a precedent case for pure policy reasons, apart from the precedent's persuasive weight on the merits of the present case. For example, under a statute abrogating stare decisis in substantive due process abortion cases, the Supreme Court would not be prevented from adhering to Roe if it found Roe's analysis persuasive. It simply would be prevented from adhering to Roe, irrespective of whether or not Roe is a correct interpretation of the Constitution, solely on the ground of adherence to the policy of stare decisis. The same applies to Casey. While such a statute would repudiate the methodology of Casey-its reliance on the policy of stare decisis as the ground for reaffirming Roe-nothing in Casey forecloses such a repudiation, since Casey makes it clear that stare decisis is merely a judicial policy, not a constitutional rule. The Court's autonomy with respect to deciding the constitutional issues on the merits would remain unaffected. The Court could adhere to the result in Casey if it found that result to be a substantively sound interpretation of the Fourteenth Amendment's Due Process Clause. Congress cannot require the Court to adhere to Glucksberg's methodology on the merits of substantive due process rather than Roe's. If the Court were to conclude that Glucksberg's approach is wrong and Roe's is right, not as a matter of stare decisis but as one of substantive meaning of the Constitution, there is nothing that

154. My brief, tentative answers to the hypotheticals I posed in the previous paragraph are as follows: Congress lacks power to control the content or manner of judicial opinion-writing: where a court has jurisdiction -literally "power to speak the law"-judges may decide in what manner of speaking they will speak the law (so to speak). A supermajority voting rule probably violates the default rule implicit throughout the Constitution for aggregating the views of multi-member bodies: majority rule. Each house of Congress may, by rule, alter this default rule for its own deliberations. See John O. McGinnis \& Michael B. Rappapon. The Constitutionality of Legislative Supermajority Requirements: A Defense, 105 YALE L.J. 483, 485 (1995). But no such power is granted to Congress with respect to the voting rule for multi-member courts, and denying the decision of a majority of judges on a multi-member court the status of a judgment of the court. contrary to the court's own view of the matuer, might well violate the prohibition against legislative alteration of final judgments of courts. Cf. Plaut v. Spendthrift Farm. 514 U.S. 211. 240 (1995) (holding that an act of Congress allowing final judgments of the judicial branch to be reopened violates separation-of-powers principles). 
Congress can do about it. ${ }^{155}$ But Congress can direct the Court not to adhere to the result in Casey simply on stare decisis policy grounds, since that policy is not constitutionally mandated and thus lies within the power of Congress to alter or displace.

Nor would a statute abrogating stare decisis impair any other exclusive powers of the judiciary identified in prior cases. ${ }^{156}$ Such a statute would not prescribe results in any particular case or class of cases; it would not dictate how the merits of any constitutional issues are to be resolved. ${ }^{157}$ (Congress might hope that, free of the policy of stare decisis, the Supreme Court would decide the merits of the abortion issue differently, but that hope rests only on the independent interpretive judgment of the Justices, not on any pretense that the statute in fact could require such an outcome.) It would not punish outcomes or decisions, and thus would not compromise the independence of the judiciary in terms of the salary, emoluments, or other benefits of the office. It would not remove any questions of law or fact from judicial resolution within the context of a case or controversy properly within a court's jurisdiction. It would not create bogus conclusive "evidentiary" presumptions under the pretext of creating procedural rules; it would thus not conscript the judiciary to perpetrate adjudicative fraud on

155. For similar reasons, explained below, Congress cannot mandate stare decisis in constitutional cases. See infra notes 161-165 and accompanying text.

156. Of course, if the theory of this Article is correct, the fact that a statute abrogating stare decisis might be deemed inconsistent with prior judicial precedent interpreting Article III would not be a persuasive argument against the constitutional validity of the statute. There is a certain circularity, however, to both the argument that precedent should be disregarded in considering whether Congress has power to direct that precedent be disregarded and the opposite argument that precedent establishes the lack of congressional power to abrogate precedent. My point here is that no Supreme Court precedent holds or suggests, directly or indirectly, that Congress lacks the constitutional power to abrogate the judicial policy of stare decisis. That fact itself-especially when combined with judicial decisions upholding other exercises of the Necessary and Proper Clause power in matters touching the case-deciding function of the judiciary, and with the Court's pronouncements concerning the nature of stare decisis as a mere rule of policy and practicepowerfully reinforces the argument for the constitutionality of such a statute. The fact that not even mutable judicial doctrine suggests a persuasive argument against the constitutionality of such a statute surely is itself entitled to some persuasive weight.

157. Cf. United States v. Klein, 80 U.S. (13 Wall.) 128 (1871) (invalidating a statute that essentially dictated the result in judicial cases by establishing a conclusive presumption concerring the legal effect of a presidential pardon in a manner inconsistent with both the President's constitutional pardon power and the Supreme Court's prior interpretation of the President's pardon power). The Klein opinion is not a model of clarity, but is probably best read for the proposition that Congress may not direct the courts to decide cases " in a particular way." Klein, 80 U.S. (13 Wall.) at 146; that is, Congress may not dictate particular outcomes (the statute at issue was not at all directed at interpretive methodology), especially not where such a directive would essentially enable one party to a dispute (the government) to direct the courts to decide a category of cases in its favor. (Another possible reading is that the statute at issuc in Klein violated the President's constitutional pardon power. Cf. supra note 119.) See PAUL M. BATOR ET al., HaRT \& WeChSLER's THE Federal CourTS AND THE FEDERAL SySTEM 369 (3d ed. 1988) (treating Klein as standing for the principle that it is "an unconstitutional invasion of the judicial function when Congress purports ... to bind the Court to decide a case in accordance with a rule of law independently unconstitutional on other grounds."). 
the public. Such a statute would not reopen final judgments. ${ }^{158}$ It would not remove from the judiciary the competency to consider any legitimate sources of inquiry into the facts of a case or the proper interpretation of the law. Courts could consider precedent and follow it if they found it persuasive; they simply could not consider themselves "bound" by it and follow it even when they found it unpersuasive, or follow it without considering the merit of the interpretations contained therein. It would not impair the competence of the judiciary to process and resolve litigation on the merits, where jurisdiction exists. ${ }^{159}$ It would not even curtail jurisdiction. In short, such a statute would impair none of the core attributes of judicial case-deciding autonomy that have been recognized in prior judicial cases and in serious scholarship explicating the contours of Article III judicial independence. ${ }^{160}$

158. See Plaut, 514 U.S. at 240. In marked contrast with Klein, the Plaut opinion is a model of clarity. But the opinion's precise expression also makes clear the narrow ground of decision: Congress may not retroactively command federal courts to reopen final judgments, because the Article III power to decide cases entails a power to decide them finally, subject to review only by other Aricle III courts in the chain of appeal. See Plaur, 514 U.S. at 218-19. Plaur's discussion makes it clear the Court's view that Congress not only may not prescribe particular outcomes in judicial cases, but also may not set aside judgments, nequire new trials, or otherwise abrogate the finality of judicial decisions by the Aricle III judiciary. See id. at 219-27. Nothing about a statute abrogating stare decisis would contradict this holding or its supporting analysis, because nothing in such a statute would reopen or set aside any final judgment in a particular case: it would merely direct that such final judgments do not bind subsequent cours in deciding the cases before them. involving different parties. Such a directive is entirely consistent with Supreme Court practice, the Supreme Court's stated doctrine, and its repeated pronouncements that the doctrine of stare decisis is a rule of practical policy, not a rule of law.

159. Professor David Engdahl has given the judiciary"s "competencly] to process and resolve litigation" within an assigned subject matter jurisdiction the apt label "judicial potency." Engdahl, supra note 152, at 82-83. A statute abrogating stare decisis would not impair judicial potency because it does not impair the competency to decide cases. It would merely remove the legislative potency of judicial decisions: the perceived power of a judicial decision in a precedent case to affect judicial decision of a subsequent case. imespective of the comectness of the precedent decision or the persuasiveness of its reasoning.

I disagree with some of Professor Engdahl's conclusions conceming what "[t]he judicial Power" of Article III necessarily entails in terms of core "judicial potency"-altributes of the judicial process with which Congress may not interfere-but those disagreements do not affect the validity of my conciusion here. One can accept Professor Enguahl's approach and readily conclude that the doctrine of stare decisis is not an attribute of "judicial polency" immune to congressional policy judgment under the Necessary and Proper Clause. even if one disagrees with some of Professor Engdahl's other conclusions.

160. For an outstanding and thorough treatment of the varieties of potential impairments of the judicial independence conferred by Aricle Ill of the Constitution, see Redish. supra note 153. Professor Redish does not address the question of congressional power to abrogate the policy of stare decisis through a statutory enactment, but his general analysis seems congenial to such a result:

When the issue concerns the power of Congress to limit federal judicial power to find sub-constitutional rules of decision, however, the attacks on congressional authority become considerably more problematic. Congress has power under Article I to adopt laws that provide substantive rules of decision in the federal courts. The unrepresentative, unaccountable federal judiciary has no authority to ignore or supplant these rules of decision, shor of a finding of [substantive] unconstitutionality. 
Instead, all such a statute would do is remove the pure "legislative" effect of prior precedents-the effect on a subsequent case attributable to precedent as a pure matter of policy, apart from its persuasiveness in assisting subsequent courts to reach what they conclude is the correct substantive understanding of the Constitution (or of federal statutes and treaties). Removing such quasi-legislative, decision-altering effect of such a judicial policy, acknowledged not to be of constitutional dimension, is easily within the power of Congress under the Necessary and Proper Clause.

\section{E. Other Possible Objections and Issues}

What about the opposite? Does the gate swing both ways? Could Congress mandate stare decisis in constitutional cases (in which case it could entrench Roe $v$. Wade or any other case)? The answer is, as I will explain momentarily, "No," and the key to this answer lies in the essentially "legislative" nature of the policy of stare decisis-the asserted power of a judicial decision in Case One to alter what otherwise would be the result in Case Two-and the effect that such a legislative policy would have on the autonomous power of courts freely to decide federal constitutional cases on their merits.

First, however, it should be noted that the premise lurking behind the question is that any power to abrogate stare decisis equally would imply a power to mandate it. The argument might take the form either of the claim that Congress may not mandate stare decisis, and thus may not abrogate it either, or that it seems nonsensical for Congress to have the power to prescribe either of two completely contradictory rules for carrying into execution the judicial power.

There is nothing inherently contradictory, however, in Congress's having a power to prescribe any of a number of possible rules on a given topic, each inconsistent with the others (as long as contradictory rules are not in force simultaneously, of course). It could well be the case that the Necessary and Proper Clause permits Congress a range of choice as to what rules to adopt governing judicial treatment of precedent, just as Congress surely has a range of legitimate choices as to the content of the rules of evidence.

Id. at 715; see also id. at 719-21 (discussing Klein). A statute abrogating stare decisis mects Redish's criteria that congressional enactments regulating judicial practice, procedure, and rules of decision not prescribe outcomes in particular cases (even though they will doubtless have an impact in individual litigation), not withdraw from the judiciary the power to decide cases in accordance with relevant facts, and not be tied to a particular substantive rule of decision but be "substantively agnostic." Id. at 721 . 
More importantly here, the existence of a constitutional power in one direction does not necessarily imply the existence of an equal-and-opposite power. For example, the Appointments Clause requires Senate confirmation of appointments of non-inferior executive branch officers, but that power does not imply a reverse power to subject removal of such officers to Senate confirmation. ${ }^{161}$ Congress has the power to declare war, but a strong argument can be made that the war power does not include the power to declare un-war. Deciding if and when to terminate hostilities, and concluding terms of peace, might be thought an aspect of the executive power, treaty power, or Commander-in-Chief power of the President, not an aspect of the legislative power of authorizing war. ${ }^{162}$ Similarly, a two-thirds Senate vote is necessary to ratify a treaty, but treaty termination is probably better thought of as an exclusively executive power. ${ }^{163}$ The point is that the question whether Congress has power to mandate stare decisis is a legal question independent of the question whether Congress has power to abrogate stare decisis. The answer to one does not dictate the answer to the other. The fact that Congress has power to abrogate stare decisis does not necessarily imply that it also possesses a converse power to mandate stare decisis, if the Constitution supplies a reason for believing that the two propositions are different.

It does. The simplest argument against a statute mandating adherence to precedent is suggested by the discussion above concerning the core meaning of "[t]he judicial Power" conferred by Article III, and the attendant limits that that meaning imposes on congressional legislative power pursuant to the Necessary and Proper Clause. ${ }^{16}$ The Article III "judicial Power" means that federal judges must be free to decide cases on the merits, without Congress telling them how to come out on a given case or particular issue or placing a thumb on the scale in favor of one or another decisional outcome. A statute abrogating stare decisis would not impair this judicial power, precisely because it does not direct specific outcomes or purport to restrict, or tilt, the decision on the merits; the whole point of such

161. See Myers v. United States, 272 U.S. 52 (1926). The holding in Myers is undermined by Humphrey's Executor v. United States, 295 U.S. 602 (1935); and Morrison v. Olson, 487 U.S. 654 (1988). I offer the Appointments Clause holding of Myers merely by way of illustration: Excellent arguments can be made (and have sometimes been accepted) that a constitutional power does not imply the existence of an equal-and-opposite power to do the reverse.

162. See generally THE FEDERALIST NO. 41 (James Madison), Nos. 74, 75 (Alexander Hamilton). Even if the best reading of the War Clause is that it does not confer a congressional power to legislate "un-war," that does not mean that Congress lacks power to accomplish the same result by use of another legislative power (for example, its control over appropriations).

163. See Goldwater v. Canter, 617 F.2d 697 (D.C. Cir. 1979) (en banc) (per curiam) (ruling that the President possesses the power of treaty termination), vacated on other grounds, 444 U.S. 996 (1979) (concluding on a mixture of grounds, none commanding a majority of the Court, that the treaty-termination issue presented in Goldwater was nonjusticiable, and dismissing a suit challenging the President's termination of a treaty).

164. See supra Sections III.B, III.D. 
a statute would be to confine judges to deciding cases on the merits, without regard to extrinsic policy considerations. But a statute mandating stare decisis does place a thumb on the scale-maybe even a whole forearm-in favor of decision on the merits for the side whose position is best reflected in current judicial precedent. That limits the freedom of judges to decide cases on their merits - the core of the judicial power. To be sure, the limitation is one that purports to embrace what the judiciary has already determined to be the case. But American courts have always been free to overrule their own precedents. If the essence of Article III power is decisional autonomy on the merits of questions of law presented in cases properly within the courts' jurisdiction, a statute mandating stare decisis impairs such autonomy while a statute abrogating stare decisis furthers such autonomy. ${ }^{165}$

A more far-reaching argument, advanced in other scholarship, is the proposition that the doctrine of stare decisis is itself unconstitutional, at least in constitutional cases. ${ }^{166}$ That argument, while intriguing and important in its own right, is unnecessary to my thesis here-that stare decisis is not constitutionally required, but is a mere principle of judicial policy that Congress consequently may modify, pursuant to the Necessary and Proper Clause-and would take me far afield from that main point.

One last potential constitutional issue remains. Is there something constitutionally suspect about a statute that selectively abrogates stare decisis (for example, just in substantive due process cases or, more selectively yet, just in abortion cases)? Such charges have been brought against proposed jurisdiction-stripping statutes that were apparently motivated by opposition to particular decisions (abortion, busing, etc.). ${ }^{167}$ But a statute abrogating stare decisis, even if limited to a particular class of cases, does not disfavor any legal rights: It does not foreclose decision in favor of those rights on the merits (it merely requires that such a decision be on the merits); it does not deprive courts of jurisdiction or litigants of fora in which those rights might be vindicated (on the merits); and it does not

165. This is not to say that Congress might not be able to enact in statutory form the substance of a judicial decision interpreting the Constitution, if it has some enumerated power (o) legislate concerning the matter at issue. See generally Ira C. Lupu, Statutes Revolving in Constitutional Law Orbits, 79 VA. L. REV. 1 (1993). This does not entrench the constitutional decision as a matter of constitutional law, however. It simply creates a statutory rule where the courts have held that a congruent constitutional rule also exists. It does not purport to prevent courts from reconsidering and reversing the constitutional rule if persuaded that it is an unsound interpretation of the Constitution. The statutory rule still would exist in such event, but Congress could repeal it by the same Article I, Section 7 process it may use to adopt, amend, or repeal any other statute.

166. See supra note 38 (collecting authorities suggesting such a conclusion).

167. See, e.g., Laurence H. Tribe, Jurisdictional Gerrymandering: Zoning Disfavored Rights out of the Federal Courts, 16 HARV. C.R.-C.L. L. REV. 129 (1981) (arguing that statutes withdrawing jurisdiction from the federal courts on specific issues effectively, and unconstitutionally, shortcut the constitutional amendment process). 
remove any remedies or enforcement mechanisms for vindication of any substantive rights. Again, all it would do is require that, if such asserted rights are to be vindicated, it must be because the courts believe the Constitution in fact substantively protects such rights rather than on the basis of what a court has said in an earlier case, "whether or not mistaken." Abortion rights are disfavored by a statute abrogating stare decisis in abortion cases only if the Court concludes that abortion rights in fact are not protected by the Constitution. As noted above, the fact that the drafters of the statute sought to achieve such a result does not mean that the enactment discriminates against any legal or constitutional rights. The whole premise of such an assertion is that such rights in fact exist, and that is the very question to be decided-on the merits, free of any prescription as to what result the Court should reach. The motivation behind the law does not defeat its constitutionality, if its substantive command is within the power of Congress and violates no other constitutional right. And that is precisely the point to be decided - on the merits.

If any legal right or interest would be unfairly burdened or discriminated against by a statute abrogating stare decisis in only certain kinds of constitutional cases, it would be those rights or interests that would lose, wrongly, on the basis of stare decisis. But an abrogating statute need not, should not, and would not properly be construed as mandating stare decisis in all constitutional cases other than the types for which the statute explicitly abrogated it. Such a law, as explained above, likely would be unconstitutional; an abrogation statute thus should be construed not to command such a result if such a reading is fairly possible. ${ }^{168}$ (Congress can make such a result explicit, of course.) In short, abrogating stare decisis specifically in abortion cases does not mandate stare decisis in other cases. The default judicial policy would remain unaffected; it would be up to the judiciary to decide whether to accord its prior cases decision-altering weight, as against what the judiciary otherwise would conclude is the correct understanding of the Constitution. ${ }^{169}$

168. See, e.g., Jones v. United States, 119 S. Ct. 1215. 1222 (1999) (collecting cases supporting the canon that statutes are to be construed to avoid constitutional difficulty if fairly possible).

169. Obviously, the best approach would be to abrogate stare decisis in all constitutional cases. If Congress chooses to proceed one step at a time, however, or perceives the need to abrogate stare decisis more urgently in the area of substantive due process or abortion specifically. it is not unconstitutional for Congress simply to take that one step.

Similarly, Congress need not attempt to prescribe that lower cours are free to disregard erroneous decisions of higher courts. While I believe that, as a matter of first principles. lowercourt judges' oaths require them to adhere to the Constitution and federal statutory and treary law rather than prior judicial decisions (of any level of court) departing from these sources of law, see Paulsen, Accusing Justice, supra note 9, at 77-88, that position is obviously controversial. A prominent judge of the California Coun of Appeal who adopted this position, see Morrow $v$. Hood Communications, 69 Cal. Rptr. 2d 489, 493 \& n.5 (Ct. App. 1997) (Kline, J., dissenting). was hauled up on disciplinary charges for such action. The disciplinary inquiry lasted many 
There is great irony in any assertion that selective abrogation of stare decisis poses constitutional or fairness problems: The Supreme Court's practice today is plainly one of selective stare decisis in the first place. Precedent is followed, except when it isn't. ${ }^{170}$ If it is troubling for the policy of stare decisis to control or impel outcomes only sometimes but not at other times, the Supreme Court's present practice is exceedingly troubling. And if that "troubling" policy is cast (whether or not meritoriously) in the form of a constitutional objection-equal protection, due process of law, impairment of "rule of law values"-it is the Court's present practice that is constitutionally problematic. And if deliberate adherence to erroneous precedents in preference to the Constitution is the definition of stare decisis in constitutional cases, the Court's current practice is doubly problematic: The Court deliberately adheres to error, selectively, and explains its actions by reference to a judge-made policy that authorizes the Court deliberately to adhere to error, selectively. Nothing could be more contrary to constitutional or rule-of-law values. ${ }^{171}$

months and generated considerable heated discussion before it was ultimately dropped. See Decision and Order of Dismissal Regarding Justice J. Anthony Kline, Inquiry \#151 (Aug. 19. 1999).

The position that lower-court judges should follow their own view of the law rather than prior judicial decisions is also directly contrary to explicit decisions of the U.S. Supreme Court. See Agostini v. Felton, 521 U.S. 203, 235-36 (1997); Rodriguez de Quijas v. Shearson/American Express, 490 U.S. 477, 484 (1989); Hutto v. Davis, 454 U.S. 370, 374-75 (1982) (per curiam). That does not make the position wrong, but it does make it prudent for Congress not to attempt to abrogate "vertical" stare decisis by statute, if it hopes to have the Supreme Court agree with the constitutionality of the statute. A statute that does nothing more than specify that the same court (at whatever level) should not adhere to prior interpretations that it presently considers wrong, merely on the basis of the policy of stare decisis, would not challenge any holding of the Supreme Court. A statute abrogating vertical stare decisis would. A statute that leaves the issue untouched would not require lower courts to adhere to higher-court precedent, but it would not directly contradict Supreme Court precedent on that point either.

170. See Paulsen, Enterprise, supra note 6, at 681 . Consider just a few notable constitutional examples over the past ten years. In 1991, the Court overruled prior constitutional precedent in Payne v. Tennessee, 501 U.S. 808, 817-30 (1991), rejecting the argument that stare decisis commanded a different result. The next year, 1992, the Court adhered to constitutional precedent (in part) in Casey, but overruled two other abortion decisions. See supra note 4. Three years later, in 1995, the Court overruled a major constitutional precedent, with Adarand Constructors v. Peña, 515 U.S. 200, 227-31 (1995), which overruled Metro Broadcasting v. FCC, 497 U.S. 547, 563-66 (1990). And in 1997, the Supreme Court, in Agostini v. Felton, 521 U.S. 203, 216, 218-24 (1997), overnuled Aguilar v. Felton, 473 U.S. 402, 413 (1985), although the Court noted that the real overruling had been accomplished, sub silentio, in 1993, in Zobrest v. Catalina Foothills School District, 509 U.S. 1, 12-13 (1993).

171. If a selective statutory abrogation of stare decisis is constitutionally underinclusive, the remedy should be to expand the abrogation, not to contract it. Somewhat revealing, however, is how hard it is to come up with an example of a major constitutional decision of the Supreme Court within the past thirty years, other than Casey, that seems to rest quite so heavily on the doctrine of stare decisis. While the Court's opinions often seem excessively precedent-focusedtaking prior cases as their starting point, rather than first principles of constitutional text, structure. and history-they rarely seem precedent-bound in the sense that the Court reaches a result contrary to its apparent inclinations solely or largely because of the stare decisis effect of past decisions. Casey is really quite striking in this respect. 
A statute abrogating stare decisis may be unfamiliar and, in some ways, threatening to widely shared assumptions about the role and usefulness of precedent in constitutional adjudication. But, as noted at the outset of this Article, unfamiliarity does not equal unconstitutionality. Upon inspection, all of the possible objections to the constitutionality of such a proposal dissolve fairly readily. The Constitution does not require stare decisis, and stare decisis is not a core attribute of the judicial power created by Article III. It is a judicial policy. Congress possesses the power under the Necessary and Proper Clause to legislate concerning matters of judicial policy-laws for "carrying into execution" the judicial power-in ways that it thinks are most conducive to the effective and correct operation of the judicial branch, so long as such laws are neither substantively unconstitutional nor unconstitutional intrusions into areas of judicial power that the Constitution has vested exclusively in the judiciary. Unless the Supreme Court is prepared to say what it has never said before (and, indeed, has repeatedly denied)-that stare decisis is constitutionally mandated or that the power to give prior precedents controlling weight is an inherent power of the judiciary bestowed by Article III and not a mere rule of policy and judicial practice-and unless the Court is willing to call into question the Rules of Decision Act, the Full Faith and Credit Act, the AntiInjunction Act, and its own decisions upholding congressional elimination of prudential standing requirements, a carefully drawn statute abrogating the doctrine of stare decisis in some or all categories of constitutional cases should be upheld and applied by the Supreme Court and by federal courts generally.

\section{CONCLUSION: BUT WILL IT FLY, WILBUR?}

The fact that a proposed statute is constitutional, under a sound understanding of first principles and even under the Supreme Court's own precedents, does not guarantee that the Court will embrace it. The most serious objections to a statute abrogating stare decisis in abortion cases are (1) that the Supreme Court will simply adhere to Roe and Casey on the basis of the asserted substantive correctness of those decisions, quite apart from considerations of stare decisis; and (2) that, alternatively, notwithstanding the force of the arguments for Congress's legisiative power under the Necessary and Proper Clause, the Court will simply arrogate to itself an inviolable power to adhere to the policy of stare decisis, in spite of the statute, on the ground that the judicial power necessarily entails an uncheckable power of courts to decide cases according to whatever principles they choose, including selective stare decisis.

The first objection assumes that the Court's invocation of stare decisis in Casey was essentially dishonest-a cover for a desired substantive 
outcome-or that enough votes have switched since Casey to make a majority for the proposition that Roe's substantive due process holding was essentially correct (a possibility seemingly negated by Glucksberg). The second objection (and perhaps the first as well) assumes that the Court will sometimes decide legal issues out of pique, and that irritation or affront at the impudence of Congress in passing statutes the premise of which is that the Court has done something wrong will lead the Court to find a way to slap Congress down, even if there is not a truly principled basis for its action and even if doing so requires it to undo or distinguish actions it has taken in the past. ${ }^{172}$ Both objections assume the existence, to some extent, of an imperialistic attitude by the Court-that the Court systematically strives to preserve and enhance its political power relative to the other branches and with respect to the governance of the nation as a whole, rather than (necessarily) seeking to decide cases in accordance with the Constitution. It will sacrifice the latter to the former, as long as its decision can be cast in terms "sufficiently plausible to be accepted by the Nation." 173

If such an attitude exists (or persists), there is a limit to what can be done to rein in judicial imperialism through the ordinary constitutional powers of Congress. If the judiciary is unwilling to accede to such legislative strictures, even when plainly constitutional, there is no course remaining, short of constitutional confrontation with the Court's assertions. If the Court as a whole, out of arrogance or self-interest, resists constitutionally legitimate congressional efforts to check unprincipled judicial action that persists in opposition to the Constitution, perhaps Congress and the President legitimately may treat the Court's decisions as

172. City of Boerne v. Flores, 521 U.S. 507 (1997), seems to be an illustration of this phenomenon. The Court's arguments in the case can be (and have been) criticized effectively. See Douglas Laycock, Conceptual Gulfs in City of Boerne v. Flores, 39 WM. \& MARY L. REV. 743 (1998); McConnell, supra note 82 . However, a more direct and equally pertinent observation about Boerne is that the Court simply resented a statute whose explicit premise was that the Court's earlier decision in Employment Division v. Smith, 494 U.S. 872 (1990), interpreting the Free Exercise Clause, was wrong and should be rendered an effective nullity. Behind the (weak) reasoning of Boerne lies thinly veiled judicial hostility to Congress's asserting any role as interpreter and enforcer of the Bill of Rights, if that role involves Congress's assertion that the Court has misinterpreted the Constitution in an important way. Without much exaggeration, Boerne may be taken as a judicial supremacist statement that Congress may not pass an otherwise constitutional statute if it insults the Court's sense of its own dignity and supremacy.

173. Casey comes shockingly close to saying exactly this:

The Court must take care to speak and act in ways that allow people to accept its decisions on the terms the Court claims for them, as grounded truly in principle, not as compromises with social and political pressures having, as such, no bearing on the principled choices that the Court is obliged to make. Thus, the Court's legitimacy depends on making legally principled decisions under circumstances in which their principled character is sufficiently plausible to be accepted by the Nation.

Planned Parenthood v. Casey, 505 U.S. 833, 865-66 (1992) (emphasis added). 
void. ${ }^{174}$ If individual Justices are shown to have acted in bad faith-if a Justice has deliberately decided a case contrary to law or advanced a rationale for a decision not honestly believed-Congress could, in theory, consider impeachment as a potential remedy for what it believed to be such intentional judicial misconduct. ${ }^{175}$

But this is strong medicine-too strong, probably, to be accepted in our constitutional politics and stronger, one would hope, than should be needed. The premise of this Article has been that Congress, the President, and We the People should be able to take the Supreme Court at its word with respect to the limited status of stare decisis as a doctrine of policy. A further premise has been that a controlling bloc of Justices in the Casey case honestly believed that their hands were tied by the doctrine of stare decisis-that is, that the stated rationale of Casey was advanced in good faith-and that these members of the Court might be open to a fuller reconsideration of the merits of the abortion decisions if relieved of the perceived burden of following the Court's own precedents. Congress could be "blamed" for any difference in outcome, with the Court's own prestige, credibility, and the like-factors so important to the Court's reliance on the judicial policy of stare decisis in Casey-unimpaired. ${ }^{176}$

Assuming good faith on the part of the Justices, Congress may in good faith adopt a policy with respect to the doctrine of stare decisis that requires the Court to decide cases like Casey based on the Justices' good-faith interpretation of the Constitution-and the Constitution alone. That small step might avoid larger, more confrontational ones. Yet that step, if

174. $C f$. id. at 865 (" [A] decision without principled justification would be no judicial act at all."). For a general statement of the theory that each branch possesses legitimate constitutional authority to resist in good faith the interpretive positions of the others that they believe depan from a correct understanding of the Constitution. see Paulsen. supra note 95.

175. See Gary Lawson \& Christopher D. Moore, supra note 119, at 1312 n.209 (")[W]c see no escape from the conclusion that Congress has the power to impeach and remove judges who do not, in the ultimate judgment of Congress, decide cases in accordance with goveming law.").

176. As a practical matter, it is probably true that this is most likely to be the case only after at least some new appointments to the Court. Yet Casey shows that new appointments alone are not always sufficient to accomplish the overruling of major cases. On the basis of their prior votes, Justices O'Connor and Kennedy should have voted to sustain the entirety of the Pennsylvania statute at issue in Casey, and probably overnuled Roe at least to the extent it was inconsistent with such an outcome. But they did not. Assuming that they were acting in (intended) good faith, the outcome and opinion in Casey shows the enormous political and psychological pressure that can be placed even on life-tenured Justices whose commitment to a particular substantive interpretation of the Constitution is not strong, on behalf of an existing decision that has acquired a large and influential political constituency. The case also shows the perceived pressure of stare decisis as a constraint on judicial action (at least in the absence of congressional action) on such Justices. It is entirely possible that future "conservative" judicial appoinices to the Court-at least, those who could survive the confirmation process-could succumb to, or perceive, similar pressures not to overrule Roe, absent action by the political branches providing an alternative institution in which the Court (and political constituencies) can locate political responsibility for the outcome. 
accepted by the Court, could have a significant impact on the substance of American constitutional law. 